\title{
Mapping digital businesses with Big Data: some early findings from the UK
}

\author{
Max Nathan ${ }^{1 *}$ and Anna Rosso ${ }^{2 * *}$ \\ ${ }^{1}$ National Institute of Economic and Social Research and London School of Economics \\ ${ }^{2}$ National Institute of Economic and Social Research \\ * Corresponding author. National Institute of Economic and Social Research, 2 Dean Trench St, \\ London, SW1P 3HE. m.nathan@niesr.ac.uk. +44 2072227665. \\ ** Present address. Department of Economics, Management and Quantitative Methods (DEMM), \\ University of Milan, Via Conservatorio 7, 20122 Milan, Italy.
}

\begin{abstract}
[144 words]
Governments around the world want to develop their ICT industries. Researchers and policymakers thus need a clear picture of digital businesses, but conventional datasets and typologies tend to lag real-world change. We use innovative 'big data' resources to perform an alternative analysis for all active companies in the UK, focusing on ICT-producing firms. Exploiting a combination of observed and modelled variables, we develop a novel 'sector-product' approach and use text mining to provide further detail on key sector-product cells. We find that the ICT production space is around $42 \%$ larger than SIC-based estimates, with around 70,000 more companies. We also find ICT employment shares over double the conventional estimates, although this result is more speculative. Our findings are robust to various scope, selection and sample construction challenges. We use our experiences to reflect on the broader pros and cons of frontier data use.
\end{abstract}

JEL C55, C81, L63, L86, O38

Keywords Big Data, text mining, ICTs, digital economy, industrial policy, firm-level analysis 


\section{1/ Introduction}

This paper uses novel 'big data' sources to expand our understanding of digital businesses in the UK. We produce alternative counts of ICT-producing firms and set out key descriptive characteristics. We then draw on this experience to critically reflect on some of the opportunities and challenges presented by big data tools and analytics for economic research and policymaking.

Information and Communications Technologies (ICTs) - and the 'digital economy' they support - are of enduring interest to researchers and policymakers. Digital sectors and firms are the subject of much analysis both at the organisational level (Bloom et al., 2012; Bresnahan et al., 2002) and in the growth field. Human capital and innovation shape long term economic development (Lucas, 1988; Romer, 1990); high value-added sectors such as ICT make direct contributions to national growth, as well as indirect contributions through spillovers and supply chains (Audretsch and Feldman, 1996; Moretti, 2012).

National and local government are thus keen to exploit the growth potential of digital businesses. Given the recent resurgence of interest in industrial policy across many developed countries (Aghion et al., 2013; Aiginger, 2007; Block and Keller, 2011; Harrison and Rodríguez-Clare, 2009; Mazzucato, 2011; Rodrik, 2004), there is now substantial policy interest in developing stronger, more 'competitive' digital economies. For example, the UK's new industrial strategy agenda (Cable, 2012) combines horizontal interventions with support for seven key sectors, of which the 'information economy' is one (Department for Business Innovation and Skills, 2013). The desire to grow high-tech clusters is often prominent in the policy mix - recent examples include the UK's Tech City initiative, Regional Innovation Clusters in the US and 'smart specialisation' policies in the EU (for a review see Nathan and Overman (2013)).

Real-world features of an industry tend to evolve ahead of any given industrial typology. For researchers, these data challenges present particular barriers to understanding the extent and nature of ICT production, where the pace of change can be very rapid. Data coverage is often imperfect, industry typologies can lack detail, and product categories do not closely align with sector categories. For policymakers, these information gaps feed through into policy gaps, which can limit the ability to design effective interventions. 
To tackle these issues we use an innovative commercial dataset developed by Growth Intelligence (hence Gi). This covers the entire population of active UK companies, and deploys an unusual combination of public administrative data, observed information, and modelled variables built using machine learning techniques. We use this off-the-shelf material to develop a novel 'sector-product' mapping of ICT firms. We also text-mine elements of the underlying raw data to explore key sector-product cells. We run these analyses on a benchmarking sample of companies that allows direct comparisons of conventional and big data-driven estimates. The differences are non-trivial: in our alternative estimates we find that the 'ICT production space' is around $42 \%$ larger than SIC-based estimates, with around 70,000 more companies. We also find employment shares over double the conventional estimates, although this result is more speculative.

This proof of concept exercise highlights both affordances and limitations of big data-driven analysis. This is critically important for the research community, as the use of non-traditional / unstructured sources, and scraping/mining/learning tools, is growing rapidly in the social sciences (Einav and Levin, 2013; King, 2013; Varian, 2014). Enthusiasts point to huge potential in closing knowledge gaps, and taking research closer to the policy cycle. Sceptics highlight potentially limited access and relevance of these 'frontier' datasets. We talk through issues of access and relevance, as well as coverage, reliability, quality and working practices that researchers are likely to encounter.

The paper is structured as follows. Section 2 sets out a basic analytical framework. Section 3 introduces the Growth Intelligence dataset and other data resources, and outlines potential pros and cons of 'big data' approaches. Sections 4 and 5 detail our sample construction and mapping strategies. Sections 6 and 7 give descriptive results. Section 8 concludes.

\section{2 / Framework}

\section{1 / Definitions}

The 'digital economy' is an economic system based on digital technologies (Negroponte, 1996; Tapscott, 1997). This is an interlocking set of sectors (industries and firms), outputs (products and services, and the content these are used to generate), and a set of production 
inputs used at varying intensities by firms and workers across all sectors (OECD, 2011, 2013). We focus on the production side, and map both industries and outputs. We ignore inputs, as it is now hard to think of any economic activity where digital inputs do not feature (Lehr, 2012; OECD, 2013).

The standard OECD/UN definitions of digital producer activity are detailed product/service groups identified by an expert panel: which are then aggregated to less detailed 4-digit standard industry codes (SICs) (OECD, 2011). ${ }^{1}$ That is, the definition moves from finegrained to rougher grained, and is typically one-dimensional. By contrast, we are able to use industry and product information for our alternative mapping and analytics, as we explain in Section 5 below.

The OECD's three main ICT producer groups are a) information and communication technologies (ICT), covering computer manufacture, IT and telecoms networks and services and software publishing; b) digital content, covering digital / online activities in music, TV, film, advertising, architecture, design, and e-commerce; and c) wholesale, leasing, installation and repair activities in both ICT and content 'space'. In this paper we focus on the production of ICT goods and services, rather than content developed using these tools and platforms. Specifically, we are interested in the producer sectors delineated in the UK Department of Business' 'information economy strategy' (Department for Business Innovation and Skills, 2012, 2013). We refer to firms in these industries as 'information economy businesses'.

The boundaries of the UK information economy are still a matter of debate. Some analysts prefer a very narrow definition including only ICT manufacturing; conversely, some UK industry voices want a much broader approach that includes manufacturing, services and supply chain activity (such as wholesale, retail, installation and repair). We need to take these different opinions into account: we therefore take ICT services and manufacturing as our base case (see Table 1), and show that our results are robust to narrower and broader starting sets. ${ }^{2}$

\footnotetext{
${ }^{1}$ We use the most recent agreed definitions available at the time of writing, as developed by the OECD Working Party on Indicators for the Information Society (WPIIS). WPIIS agrees product lists using UN Central Product Classification (CPC) codes, then crosswalks these onto SIC2007 4-digit cells. See OECD (2011) for detail.

${ }^{2}$ We use the whole UN/OECD set of digital economy SIC4 codes as a starting point for our analysis, then crosswalk these to 5-digit level and make some adjustments made for the information economy element in a UK context. BIS have not formally defined a set of SIC codes for the information economy, but the Department's
} 


\section{Table 1 about here}

In an earlier paper (Nathan and Rosso, 2013) we conduct exploratory analysis on both ICT and digital content activities. The latter is substantially harder to delineate in sector terms, not least because most content sectors are rapidly shifting from physical to multi-platform, online and offline outputs (Bakhshi and Mateos-Garcia, 2012; Foord, 2013) and because many product categories bleed across sector boundaries (see below).

\section{2 / Data challenges}

Counting information economy businesses is challenging, particularly when conventional administrative datasets are used. In the UK there are three principal issues.

The first issue is data coverage. The main UK administrative source for firm-level data is the Business Structure Database (BSD) (Office of National Statistics, 2010, 2012). However, the BSD only includes firms paying UK sales tax and/or those with at least one employee on the payroll. The BSD covers $99 \%$ of all UK enterprises, but for sectors with large numbers of start-ups and small young firms - such as the digital and information economies, or nanotech coverage will be substantially poorer.

The second issue is SIC code precision. SICs are designed to represent a firm's principal business activity, but also aggregate information about inputs and clients (Office of National Statistics, 2009). As the OECD (2013) has noted, SICs can be too broad to describe new industries. For this reason, firm counts for 'other' or 'not elsewhere classified' based SIC cells are often very large, even at the most detailed five-digit level. In the 2011 BSD, for example,

internal working definition is all of SIC3 cells 58.2, 61, 62 and 63 (personal communication, 28 November 2013). Following consultation with BIS we exclude the SIC5 cells 71121 ('engineering design activities for industrial processes and production') and 71122 ('engineering-related scientific and technical consulting activities') specified by the OECD (personal communication, 2 December 2013). Conversely, we exclude the BIS-specified cells 63910 ('news agency activities') and 63990 ('other information service activities not elsewhere classified') because they are included in the UN/OECD list of content sectors, rather than ICT production. Our robustness checks cover ICT services only (excluding all the sectors in the ICT manufacturing, code 26) and a broader set of SICs comprising manufacturing, services and supply chain activity. See Section 6. 
the second largest ICT cell is 'Other information technology service activities' (62090) which contains 22,444 enterprises (compared to 66,090 in 'Information technology consultancy activities', cell 62020).

A third, related issue is that products and services often cross sector boundaries. In the OECD analysis 'software publishing', SIC 5820, contains 10 product/service groups; conversely, the products 'data transmissions services' and 'broadband internet services' are present in multiple SIC cells (6110 through 6190). Cross-sector product types are even more prevalent in digital content activities (OECD, 2011).

\section{3 / Can Big Data help?}

These data challenges highlight a more fundamental issue. Real-world industries, products and services are constantly evolving, while administrative typologies designed to describe them are essentially static with periodical revisions. This means that for any given iteration of an administrative typology, there is always a gradual divergence between the real features of a given economy and the means of representing those features in code form. In industries such as ICT, where entry barriers are low and the pace of innovation rapid, this divergence will be particularly marked.

It is for these reasons that we might turn to big data sources and techniques. 'Big data' is a complex concept that needs careful specification. We follow Einav and Levin (2013), who define 'big' datasets as those that a) are available at massive scale, often millions or billions of observations; b) can be accessed in (close to) real time; c) have high 'dimensionality', that is, cover many variables including phenomena previously hard to observe quantitatively, and d) are much less structured than 'conventional' sources, such as administrative data.

The use of such datasets and associated analytical techniques - web scraping, text mining and statistical learning - is growing in the social sciences (King, 2013; Varian, 2014). Wellknown examples include analysis of internet search data (Askitas and Zimmermann, 2009; Choi and Varian, 2012; Ginsberg et al., 2009); proprietary datasets, such as those derived from mobile phone networks (Di Lorenzo et al., 2012); and material derived from texts, both historic (Dittmar, 2011) and contemporary textual information taken from the Web, political speeches, social media or patent abstracts (Couture, 2013; Fetzer, 2014; Gentzkow and 
Shapiro, 2010; Lewis et al., 2011). Structured administrative datasets also take on 'big' features when linked together, or enabled with APIs that allow researchers to download online material. In the UK, virtual environments such as the Secure Data Service (SDS) and HMRC DataLab provide researchers with secure spaces for matching, and several government agencies are putting data online with API functionality.

In theory, big data should help us to develop much stronger measures of the extent and characteristics of digital economy businesses (and other nascent high-value sectors such as clean technology). Our dataset, for example, is built on an API-enabled 100\% sample of active companies in the UK which is updated daily, and combines both public (administrative, structured) and proprietary (unstructured, modelled) layers which are matched to the base layer using firm names and other company-level details. These qualities of speed, scale and additional dimensions should help researchers to tackle the information economy evolution, measurement and mapping challenges described earlier.

Conversely, big data approaches may turn out to have important limitations for academic research. Einav and Levin (2013) discuss two of these: limits on access to proprietary datasets, and the potentially limited relevance of much business data to public policy-focused research questions. Other issues include coverage (for instance, of companies not present in scraped/mined sources), reliability (when variables are probabilistic rather than directly observed, and when data is sampled), and overall quality (proprietary datasets may not be validated to the standards of administrative sources, or at all). Our experience highlights many of these pros and cons.

\section{3 / Data}

Our main dataset is commercial company-level information provided by Growth Intelligence (growthintel.com). Growth Intelligence (hence Gi) is a London-based firm, founded in 2011, that provides predictive marketing software to private sector clients. The Gi dataset is unusual in the 'big data' field in that it combines structured, administrative data and modelled information derived from unstructured sources. The simplest way to describe the data is in terms of layers. This section provides a summary: more details are available in Appendix 1. 


\section{1 / Companies House layer}

The 'base layer' is the population of active companies in the UK, which is taken from the Companies House website and updated daily. Companies House is a government agency that holds records for all UK limited companies, plus some business partnerships. (Sole traders are not covered, so to the extent that they work in ICT, our estimates are lower bounds.) Companies are required to file annual tax returns and financial statements, which include details of company directors, registered office address, shares and shareholders, company type and principal business activity (self-assessed by firms using SIC5 codes), as well as a balance sheet and profit/loss account. In some cases companies also file employee data (as part of the accounts, or when registering for small / medium-size status which carries less stringent reporting requirements). Coverage of revenue and employment data in Companies House is limited - around $14 \%$ of the sample file revenue data, and 5\% employment data, and these samples may be positively selected (as poor performers may try to avoid public filings). For this reason, descriptive results should be interpreted with some caution.

\section{2 / Structured data layers}

Gi matches Companies House data to a series of other structured administrative datasets, such as patents, trademarks and US exports. Gi uses these structured datasets in two ways: to provide directly observed information on company activity (for example, patenting), and as an input for building modelled information about companies - for example, text from patent titles as an input to company sector / product classifications, which we discuss below.

\section{3 / Proprietary layers}

This part of the Gi dataset is developed through 'data mining' (Rajaraman and Ullman, 2011). Gi develops a range of raw text inputs for each company, and then uses feature extraction to identify key words and phrases ('tokens'), as well as contextual information ('categories'). These are taken from company websites, social media, newsfeeds (such as Bloomberg and Thomson Reuters), blogs and online forums, as well as some structured data sources. Using workhorse text analysis techniques (Salton and Buckley, 1988), Gi assigns weights to these 'tokens', indicating their likelihood of identifying meaningful information about the company. Supervised learning approaches (Hastie et al., 2009) are then used to develop bespoke 
classifications of companies by sector and product type, a range of predicted company lifecycle 'events' (such as product launches, joint ventures and mergers/acquisitions) and modelled company revenue in a number of size bands. Tokens, categories and weights are used as predictors, alongside observed information from the Companies House and structured data layers.

\section{4 / Pros and cons of a Big Data approach}

The Gi dataset should allow us to tackle the measurement challenges outlined in Section 2. First, compared to administrative data sources, the Gi data has greater coverage and provides substantially more information (thanks to the matched and modelled layers). Second, classifying companies by sector and product should allow us a more precise delineation of ICT producing companies. Specifically, SIC5 codes provide 806 sectors in which to place companies, but Gi's 145 sector and 39 product groups provide 5,510 possible sector-product cells, a more than six-fold increase. Being able to examine products, sectors and token-level information within sector-product cells affords additional detail than administrative sources and SICs cannot provide.

Conversely, there are some potential limitations in the Gi dataset. Most importantly, while our data is based on the population of UK companies, coverage of some elements is not comprehensive. This gives us 'sampled' elements to the dataset, but without an explicit process of random sampling to generate the data. To draw inferences from the data, therefore, we need to understand and work around coverage / non-response issues. ${ }^{3}$

First, coverage of online sources is imperfect. Many companies in the UK do not have a website, and not all websites can be successfully scraped due to site content or build; Gi estimates around 500,000 companies have websites and have scraped around 50\% of these. ${ }^{4}$ While 'non-scrapability' is likely random, having a website is not. Of course, a large number of companies without websites will be inactive or connected to an active enterprise that is online; we clean these 'untrue' companies out of our estimation sample (see Section 4). For the rest, GI's modelled variables also draw on a range of online and offline sources for

\footnotetext{
${ }^{3}$ We are grateful to a referee for highlighting this point.

${ }^{4}$ Sites which use predominantly Flash or are out of order / 404 cannot be tokenised.
} 
modelled data, which further helps deal with potential bias. Very few companies have no observed or modelled information at all: these comprise less than $0.1 \%$ of the raw data, and are dropped from our sample.

Second, while the company has conducted some validation exercises on its modelled variables (see Appendix 1) Gi's core code is proprietary, which limits our availability to do forensic quality checking. However, we are able to conduct our own checks by comparing estimates derived from Gi's modelled data against those derived from directly observed information. Section 4 gives more details.

\section{4 / Building a benchmarking sample}

Our raw data comprises all active companies in the UK as of August 2012, and comprises $3.07 \mathrm{~m}$ raw observations, of which $2.88 \mathrm{~m}$ have postcodes. From this we need to build a sample that a) corresponds as closely as possible to the underlying set of businesses, and b) allows comparisons between digital economy estimates based on SIC codes and those based on modelled big data. Our cleaning steps are as follows.

First, this 'benchmarking' sample can only include observations with both SIC codes and Gi classifications. Because around $21 \%$ of companies in the raw are missing SIC information it will therefore be smaller than the 'true' number of companies. In some cases, we can crosswalk SIC fields from the FAME dataset to reduce losses. Overall, these steps reduce our sample from $2.88 \mathrm{~m}$ to $2.85 \mathrm{~m}$ observations.

Second, we drop all companies who are non-trading, those who are 'dormant' (no significant trading activity in the past 12 months), dissolved companies and those in receivership / administration. We keep active companies in the process of striking off, since a) most still operate and b) some will have failed to file returns but may re-emerge in the market under a 
different name. These steps reduce our sample to $2.556 \mathrm{~m}^{\text {companies. }}{ }^{5}$ We also drop holding companies from the sample, which reduces it to $2.546 \mathrm{~m}$ observations.

Third, we build routines to identify groups of related companies, and reveal the underlying structure of businesses. Companies are legal entities, not actual firms, so this is a crucial step to avoid multiple counting in the underlying firm structure (for instance, if company A is part of company B, it may include some of B's revenue / employment in its accounts). This step is necessarily fuzzy, as we are creating 'quasi-enterprises'. We do this in two ways, both of which deliver very similar results. Our preferred approach is to group companies on the basis of name (same name), postcode of registered address (same location) and SIC5 code (same detailed industry cell). ${ }^{6}$ Within each group thus identified, we keep the unit reporting the highest revenue (as modelled by Growth Intelligence). Note that for the purposes of benchmarking, we are required to do the industry matching on SIC code. This procedure gives us a benchmarking sample of $1.94 \mathrm{~m}$ quasi-enterprise-level observations. ${ }^{7}$

We also test an alternative approach that exploits corporate shareholder information matched from FAME. The intuition is that if company A owns more than $50 \%$ of company $\mathrm{B}, \mathrm{A}$ is likely to report B's revenue and employment. We drop B from the sample in these cases. This approach gives us a benchmarking sample of $1.823 \mathrm{~m}$ observations. Headline results from this alternative approach are in line with our main results set out in Section $6 .^{8}$

\footnotetext{
${ }^{5}$ Dropping non-trading companies removes 92,929 observations; dropping dormant companies removes 106,589 observations; dropping all but active and partially active companies removes 318,906 observations. Some companies may be in more than one of these categories, so sub-totals may not sum.

${ }^{6}$ We do not use the full company name, but we use the first if there is only one word in the name of if the second word is some common acronyms that refer to the status of the company (Limited, Ltd, Plc, Company, LLP) in all their forms. We use the first and the second words if there are at least two words in the name or the third word is again an acronym as in the previous case.

${ }^{7}$ We test the sensitivity of this approach by matching on postcode sector (that is, the first 4/5 digits of the postcode) rather than the full postcode. This less restrictive approach would reduce false negatives (related companies that are very closely co-located but not present at exactly the same address), but might increase false positives (similarly-named but non-related companies in the same industry and neighbourhood). Results show that company counts decline in almost the same proportions across all sectors. This is reassuring, as it implies that there is nothing systematic happening in our selection process. Details are available on request. ${ }^{8}$ Specifically, using SIC-based definitions we have 158,810 ICT producer companies (8.17\%) compared to 225,800 companies $(11.62 \%)$ using the 'sector-product' approach. See Table 2 for headline comparisons.
} 
We validate our cleaning steps by comparing the size of a 'true' sample of all quasi-enterprises against counts of actual enterprises in a) the 2011 BSD and b) the 2012 UK Business Population Estimates (the most recent available at the time of writing). The BSD contains $2.161 \mathrm{~m}$ enterprises, but excludes sole traders and many SMEs. Our 'true sample' of quasienterprises contains 2.460m observations as of August 2012, so the BSD figure is within 88\% of this: acceptable given the differences in time and sample coverage. The BPE is a more helpful benchmark since it combines BSD enterprises with estimates for non-BSD businesses and sole traders (some of whom will be in our sample if they have registered a company). The BPE gives estimates up to January 2012; to make the comparison cleaner we estimate an August 2012 figure. We include companies, partnerships and sole traders with employees, plus $10 \%$ of other sole traders as a proxy for single-owner registered companies. This gives a January 2012 baseline of 2.36m enterprises. When project smoothed 2011-2012 through to August. This gives a figure of $2.45 \mathrm{~m}$ businesses, within $99 \%$ of our true sample estimate. ${ }^{9}$

We also test the robustness of our benchmarking sample structure. This is important to explore, as firms registering at Companies House assign themselves a SIC code. Companies doing novel activities not well covered in SICs might systematically select into 'not elsewhere classified' SIC bins rather than their 'true' classification. The set of information economy SICs contains quite a lot of these, which might lead to upwards bias. Conversely, selfassignment might lead to missing SICs for information economy firms, leading to undercounts.

Specifically, we compare across all five-digit SIC bins in Companies House with those in the 2011 BSD. Appendix 2 sets out the analysis. We find that the different population frames of the BSD and Companies House produce some differences in levels and internal structure, reflecting real differences in company and sector characteristics, such as firm age, industry structures and entry barriers. The overall distribution of Companies House and BSD SIC5 bins is well matched. Around the extremes, we find a number of 'not elsewhere classified' type bins where Companies House counts are higher than the BSD. These bins account for just over $10 \%$ of all the data, but only four out of 74 of these bins are in the information

\footnotetext{
${ }^{9}$ The $2.36 \mathrm{~m}$ total includes $1.34 \mathrm{~m}$ companies, 448,000 partnerships, 297,000 'sole proprietorships and partnerships' with employees and 271,000 sole traders without employees. We also conduct sensitivity checks including 1) $5 \%$ of sole proprietors without employees (2.253m enterprises) and 2) basing on 2009-2011 trends (2.390m enterprises). Full results available on request.
} 
economy. Conversely, $21.5 \%$ of observations in the Companies House raw data lack SIC codes altogether. Taken together, this suggests that any Companies House processes (such as self-assignment) could be generating a small amount of upwards bias, but this is more than outweighed by the likely downwards bias produced by non-assignment.

\section{5 / Identifying ICT production activity}

Our benchmarking sample comprises nearly $2 \mathrm{~m}$ 'quasi-enterprises' classified with both SIC codes (based on company self-assessment), and Gi's sector and product categories (based on a range of observed and modelled information). We use this additional richness in our 'big data' to develop alternative counts of information economy firms.

Our identification job is analogous to studies that seek to map a social/economic phenomenon through analysis of structured and unstructured information, both in data mining and in related fields such as bibliometrics. These studies have important differences, but share many of the same basic steps. Each begins with a given vocabulary or item set $\mathrm{K}_{\mathrm{x}}$ describing the phenomenon $\mathrm{X}$, and which is used to analyse a much larger item set, $\mathrm{U}_{\mathrm{x}}$, for which

information about $\mathrm{X}$ is unknown. Items in $\mathrm{K}_{\mathrm{x}}$ may map directly onto $\mathrm{U}_{\mathrm{x}}$, or common features such as distinctive terms in both $\mathrm{K}_{\mathrm{x}}$ and $\mathrm{U}_{\mathrm{x}}$ - may be used to generate a mapping.

For instance, Gentzkow and Shapiro (2010) use speeches by members of the US Congress to analyse ideological 'slant' in the American media: they develop a core vocabulary of liberal and conservative politicians' most distinctive phrases, which is then mapped onto a similar vocabulary of newspaper op-ed pieces in order to estimate media affiliation. Working with patents data, Fetzer (2014) uses existing technology field codes to delineate broad spaces for 'clean' technology, then generate finer-grained technology vocabularies from patent titles and abstracts. These are then used to resample the patents data to provide an alternative mapping of the clean technology space.

Ideally, then, we would look for a rich word- or phrase-level objective vocabulary for information economy companies, $\mathrm{K}_{\mathrm{ie}}$, which we would then map onto a corpus of companylevel texts for companies. In practice, we have a category-level item set for the information economy, which is expressed in our data with SIC codes (see Section 2). And rather than raw 
words and phrases, we are working with a 'categorical vocabulary' of off-the-shelf sector and product categories mined by Gi (see Section 3).

\section{1 / Mapping strategy}

Our basic mapping steps are as follows. First, we take the sub-sample of companies with OECD/BIS ICT products and services SIC codes, as defined in Table 1. Next, we extract the corresponding Gi sector and product classifications for those companies: this provides a longlist of $99 \mathrm{Gi}$ sectors and $33 \mathrm{Gi}$ product groups. We treat this as a rough cut of the true set of ICT sectors and products/services.

Following this, we refine the cut. We first use a crude threshold rule to exclude 'sparse' Gi sectors and product cells, which might be marginal and/or irrelevant to ICT sector/product space. Sparse groups are defined as those present in less than $0.2 \%$ of the long-listed observations. Removing this group of sparse cells results in a shortlist of 16 sectors and 12 product groups, which account for the majority of ICT-relevant observations.

Next, we review the sparse Gi sector and product lists in detail to recover any marginal but relevant cells. By construction, each of these cells comprises less than $0.2 \%$ of the long-listed observations. ${ }^{10}$ The review is rule-based: specifically, we look for sparse Gi sector or product cells where the name corresponds to 1) the OECD definition of ICT products and services, or 2) BIS modifications to this list. We use the detailed OECD guidance (OECD, 2011) and Gi metadata to guide marginal decisions: we include cells that have some correspondence to the OECD-specified SIC4 or CPC group, and exclude those where no such correspondence exists. For example, we recover the sector cells 'computer network security' and 'e-learning', which feature in the OECD product list, but exclude the product cell 'hardware tools machinery', which Gi uses to designate construction tools (such as mechanical hoists).

Finally, we use this set of sectors and products to resample sector-by-product cells from the whole benchmarking sample. This creates a set of companies in 'ICT' sectors whose principal product / service is also ICT-relevant.

\footnotetext{
${ }^{10}$ We include the following sectors: e-learning', 'computer network security', 'information services', 'semiconductors'. We include the following products: 'software web application' and 'software mobile application', but we exclude: 'hardware tools machinery'.
} 


\section{2 / Identification}

This 'sector-product' approach, built on a range of data sources, provides an alternative mapping of information economy firms. It should allow us to deal with false negatives in our data (via incorrect SIC coding). It should also tackle false positives, by allowing us to identify the set of companies in 'ICT' sector contexts whose main outputs (products and services) are also ICT-related, disregarding those who are not involved in digital activity. This allows us to keep those companies in (say) the mobile telecoms industry who are actually making mobile phones, and exclude those who are involved in wholesale, retail or repairs.

We then run various robustness checks. First, as outlined in Section 2, there is some disagreement about which SIC codes should be used to delineate the information economy. Sector-product results might then be endogenous to the set of starting SIC cells, rather than being driven by real differences in sector-product information. We therefore reproduce the analysis with different SIC starting sets, both a very narrow set of ICT service industries and a broader set of manufacturing, service and supply chain industry bins.

Second, our $0.2 \%$ threshold rule might still identify some irrelevant sector / product space (leading to false positives). We experiment with tighter thresholds at $0.3 \%$ and $0.5 \%$ of longlisted observations. Third, the sector-product approach might collapse to a 'sector' or 'product' analysis, if one of the $\mathrm{Gi}$ vectors turns out to be uninformative. In this case false positives could be included in the final estimates. We test this by reproducing the analysis with $\mathrm{Gi}$ sector cells alone, and Gi product cells alone.

A final worry is that our off-the-shelf Gi categories are too high-level to always provide useable information (this objection also applies to SIC codes). In our case, we are relying on the combination of sector-by-product information: but analysis using only $\mathrm{Gi}$ sector or product typologies, or individual sector/product cells, may be less informative. We therefore use raw token information from company websites to look inside the largest sector and product cells. 


\section{6 / Results}

How do conventional and big data-based estimates of ICT production differ? Table 2, below, gives headline results. Panels A and B give alternative estimates of information economy companies. SIC coding identifies 158,810 ICT quasi-enterprises, $8.17 \%$ of our benchmarking sample. By contrast, the sector-product approach identifies 225,800 quasi-enterprises, around $11.62 \%$ of the economy. That is, our big data-driven estimates are over $40 \%$ higher compared to SIC-based definitions in Panel B. Overall, this difference in headline numbers - nearly 70,000 'missing' companies - suggests the precision gain is non-trivial.

\section{Table 2 about here}

By construction, our sample includes only those companies with SIC and Gi coding, so missing SIC codes are not driving the results. Other panels report robustness checks that explore some of the identification challenges discussed in section 5.2. Panels C and D show the effect of changing the starting set of SIC sectors. In Panel C1 we look only at SICs covering ICT services, while in Panel D1 we use a broader definition of the information economy including SIC codes in the wider ICT value chain. ${ }^{11}$ Panels $\mathrm{C} 2$ and D2 give corresponding Gi-based estimates. If our main results were entirely driven by choice of the SIC starting categories, we would find alternative SIC (sector-based) counts converging to the Gi (sector-product) estimates in Panel B. Even with the broadest starting set of SICs (Panel D1) we find 31,624 fewer companies than our baseline Gi estimates (Panel B) and 40,058 more companies in the corresponding Gi counts (Panel D2).

Panel E tests the effectiveness of the sector-product approach as opposed to using sector-only Gi information. We would expect the lack of granularity to produce higher estimates, which it does (305,177 versus 225,800 companies, almost $16 \%$ of the sample). (Using only the product dimension of Gi data, the share would be driven up to more than $50 \%$.) ${ }^{12}$

\footnotetext{
${ }^{11}$ Panel C covers ICT services only (see Table 1). Panel D includes all the SICs in Table 1 plus 33120 (Repair of machinery), 33190 (Repair of other Equipment), 33140 (Repair of Electrical Equipment), 33200 (Installation of industrial machinery and equipment), 95110 (Repair of computer and peripheral equipment), 71129 (Other engineering activities), 71122 (Engineering related scientific and technical consulting activities), 71121 (Engineering design activities for industrial process and production).

${ }^{12}$ Results available on request.
} 
The last two panels shows estimates using more conservative threshold rules to exclude sparse Gi sectors and products cells: $0.3 \%$ and $0.5 \%$ in panels F and G, respectively. Again, we would worry if the resulting counts approached the initial sector-based estimates in Panel A (indicating that the sector-product approach delivers little precision over SIC sectors). Information economy counts and shares drop as expected, but even in the most conservative specification (Panel G) we find 34,597 additional companies using sector-product cells compared to SIC sector codes.

\section{1 / What kind of additional companies?}

Our sector-product method gives us a large number of companies that we would not treat as ICT producers using SIC codes alone. Table 3 maps these quasi-enterprises back onto their SIC codes, for the 18 largest SIC cells.

\section{Table 3 about here}

Note that some of these SIC bins (33200 and 95110, 4.8\% of the total) would be included in our 'broad-based' set of information economy SIC codes, as discussed above. Another $8 \%$ $(33190,43210,46250,47410)$ also fit into 'value chain space'. However, more than $26 \%$ of the omitted companies classify themselves in the 'Other engineering activities', 'Engineering related scientific and technical consulting activities' and 'Engineering design activities for industrial process and production' bins (respectively 71129, 71122, 71121); and another 20\% define themselves in the advertising agency or specialised design sectors (such as 73110 or 74110). While these companies are in 'non-ICT' sector contexts, in other words, their principal products and services put them into the information economy.

\section{2 / Internal structure}

Next, we take a closer look at the internal structure of our Gi-based ICT producer estimates. Tables 4 and 5 provide headline counts, shares and revenue information for the largest sectorproduct cells. Each table 'rotates' the cells to indicate sector information (Table 4) and product information (Table 5), so that companies in (say) the 'computer games' sector could have any of the principal outputs listed in the products table - and companies whose principal 
product is (say) 'consultancy' might be in any of the sector cells in the sector table. (Together, all of these combinations would form a 378-cell matrix too large to show here.)

\section{Table 4 about here}

More than $46 \%$ of companies in Table 4 are located in information technology, almost $15 \%$ in computer-related sector groups (computer software, hardware, games), around $20 \%$ in engineering and manufacturing sectors, and a further $7 \%$ in telecommunications.

\section{Table 5 about here}

Table 5 shifts the focus to products and services. Most of the companies are providing some kind of consultancy service (67\%), offering software development (8.8\%), care and maintenance (7\%), web hosting (just under 3\%) or some sort of broadband or software related services.

This analysis of within-structure starts to give a sense of what firms in the information economy are offering in the product/service mix. The main impression is of technological diffusion outside computer hardware and software into other industries: notably engineering and manufacturing sectors, but also digitised consultancy and business services. As we discuss in Section 2, our analysis is likely capturing evolving activities, products and services that do not show up easily in administrative classifications.

To build on this, we use text mining to uncover more information about the largest cells, 'information technology' and 'consultancy'. ${ }^{13}$ To do this we use raw text data (tokens) and

\footnotetext{
${ }^{13}$ We have run some statistical tests in order to check how different the sample of tokens is in comparison to the whole sample of companies (benchmarking sample), both in terms of within sectoral distribution (share of ICT companies) and in terms of characteristics to conclude that the information economy sector when defined using SIC codes is around $8 \%$ (similarly to the whole sample). When defined using Gi definition the information economy is slightly overrepresented in the token sample, it is likely to be the case as Gi algorithms puts more weight to the presence of web tokens when assigning a company to a sector. Sectors/products where token information is better (in particular it is likely that ICT sectors do have a better internet coverage) are likely to be larger. In terms of characteristics, ICT companies in the token sample are likely to be older, and have higher revenues. All the differences are statistically significant.
} 
contextual information (token categories) taken from websites and news feeds (see Section 3). Gi reports 12 token categories of which we use four - organization, product, technical term and technology. ${ }^{14}$ Tokens are assigned values representing the relevance of the token for the company, ranging from 0 to 1 : we include only tokens whose company relevance is above 0.2. We harmonize token content by putting all the words into lower case, removing punctuation, and removing words that may refer to legal status of the company: 'ltd', 'plc', '1lp', 'company'. We also remove stopwords. ${ }^{15}$

In Figure 2, we report, in a word cloud, the most popular words across the whole set of information economy firms when the sector is defined using the Growth Intelligence classification as per Panel B in Table 2. For reasons of space, we only show the words that appear at least 2,000 times in the whole sample of the information economy. We end up with a list of 363 words where the total number of words is $1,839,014$. The larger and darker the word is, the more frequent it appears in the sample of companies in the information economy that report token information. For example, the most frequent word is 'technology' which appears 70,139 (4\% of the total number of words) in the sample, the word 'technology_internet' is very frequent and appears 40,286 times (2\%).

\section{Figure 2 about here}

In Table 6 we report a list of the most popular words (48\% of total number of words) in the information economy with the total number of appearances, and the relative share given by the number of appearances over the total number of words $(1,839,014)$ (Panel A). We also show the same information for the companies in the sector 'information technology' and product cell 'consultancy' (Panel B), 'consultancy' products across all ICT sectors (Panel C) and 'information technology' firms providing any ICT products (Panel D). ${ }^{16}$

\section{Table 6 about here}

\footnotetext{
${ }^{14}$ The full list of token categories is: Company, Contact Details, Entertainment Event, Location, Operating System, Organization, Person, Position, Product, Technical Term, Technology, TV Show.

15 http://jmlr.org/papers/volume5/lewis04a/a11-smart-stop-list/english.stop, accessed 15 December 2013.

${ }^{16}$ In the subsample of companies with tokens we have 3,716 companies doing IT and consultancy, 12,556 companies providing some consultancy service in any ICT sectors, and 4,296 in the information technology sector (any ICT products).
} 
The word that appears the most in panels A-C is 'technology'; for the IT sector it is 'software'. It represents $4 \%$ of the total number of words in the complete ICT producer space (Panel A), $7 \%$ in the sample including only companies doing IT and consultancy, 5\% in Panel C (consultancy) and 6\% in Panel D (IT), while 'software' in IT appears 7\% of the times. Note that the distribution across panels within these information economy cells is very similar, and despite relatively sparse some words appearing only $1 \%$ of the time, we observe a high density in the same words across all the four panels.

\section{Figure 3 about here}

We might worry that these are simply terms which appear on any company's website. To understand how distinctive these words are, then, we also look at the word distribution among the sectors in the rest of the economy (Figure 3). Interestingly, we find that the most relevant words are not the same: the words that are denser in ICT production space are underrepresented in other activity spaces.

\section{7 / Characteristics of ICT and non-ICT businesses}

This section provides descriptive analysis of companies' age, inflows, revenues and employment.

\section{1 / Age}

Table 7 reports the average age of ICT and non-ICT companies in the benchmarking sample. ${ }^{17}$ Using SIC codes, ICT companies around almost three years younger than non-ICT firms; using sector-product definitions the difference shrinks slightly. Notably, median differences between ICT and non-ICT firms are substantially smaller; the median ICT firm is now about a year younger than its non-ICT counterpart, whichever definition is used.

\section{Table 7 about here}

\footnotetext{
${ }^{17}$ We report estimates only for our preferred definition, panels A and B of Table 2.
} 
In Table 8, we show the distribution of companies by age groups. This share can easily be interpreted as a survival rate. ${ }^{18}$ Panel A uses SIC code definitions; panel B uses sector-product groups. In Panel B, around 66\% of 'ICT' companies are under 10 years old, 33\% under five years, $14.4 \%$ under three years old and around $1 \%$ less than a year old. This compares with $64.6 \%, 30.6 \%, 13.8 \%$ and $2.2 \%$ respectively in the rest of the economy. Analysing the distribution using SIC codes (Panel A) shows very similar patterns. Start-ups, usually defined as companies less than three years old, are slightly more common in among ICT producers than in the rest of the economy.

\section{Table 8 about here}

On the face of it, these findings are surprising: the popular image of the ICT industry is of start-ups and very young companies. Our evidence, however, suggests that there is no reason to think that the ICT companies are more ephemeral than the other companies. Our analysis of inflows, below, also tells a similar story.

\section{2 / Inflows}

Figure 4 shows the inflow of our companies into the economy, comparing inflows of companies into ICT production (dashed line) with companies in the rest of the economy (solid line), from 1980 to 2012. The number of ICT companies entering the economy every year has always been much smaller, but it is interesting to see that when using Growth Intelligence's classification we are able to capture a higher level of inflow over the whole period considered but in particular after the year 2000 .

\section{Figure 4 about here}

We also estimate the growth rate, defined as the percentage of the yearly inflow over the total existing companies and compare it across the two sectors. Results are shown in Figure 5.

\footnotetext{
${ }^{18}$ We have looked at companies that dissolved in year 2012, which have dropped from the selected sample. We have looked at the distribution of companies by incorporation year and by sector and also in this case, the distribution over time is similar in the ICT sectors and in the rest of the economy. This also implies that the average age is similar and it is actually higher for the digital economy sectors when using Gi definition.
} 


\section{Figure 5 about here}

The growth rate of ICT companies has been higher than the rate in the rest of the economy in the period before the dot-com bubble which happened in year 2000, and this is even more evident when using the SIC codes. The reason why the rate is smoother in the Gi-based classification may be related to the fact that when using our alternative definition we are also capturing companies that have been in the economy for a longer period and started to produce products or provide services that we would include in the ICT definition. After the dot-com bubble, the information economy started to follow the cycles of the rest of the economy, and the growth rate even started to be lower than the rate in other sectors.

\section{3 / Revenue}

Regular Companies House data provides relatively limited information on company revenues. Only $13.9 \%$ of the companies in our sample have reported revenues in the period between 2010 and 2012 and even a smaller percentage (8.4\%) have filed revenues every year over the same period. We therefore supplement this information with Gi's modelled revenue data, which covers all of the companies in the dataset.

\section{Table 9 about here}

Table 9 sets out these two sources together. We can see from Panel A that the sub-sample of companies reporting revenues is similar to the full sample in terms of information economy shares. For this sub-sample, non-ICT companies have higher average and median revenues, but on Growth Intelligence's measures the gaps between the two groups narrow substantially. When shifting to modelled revenue, ICT firms have lower average revenue but rather higher median revenue than non-ICT firms. In Panel B, we look at 2010-2012 revenue growth for the companies who report revenues over more than one year. The first column reports the average percentage growth, defined as the within-firm growth of revenues averaged over the sample. On the sector-product basis, growth is higher for ICT companies (22\%) than the rest of the economy $(15 \%)$ - with similar results for SIC-based definitions. Median differences are rather smaller. 
Table 10 takes a higher-level view of modelled revenue across the whole benchmarking sample. Average revenues for ICT firms run at around $40 \%$ of the non-ICT average for SIC definition but slightly higher on the sector-product. Looking at medians, non-ICT firms have slightly lower modelled revenue than ICT firms using both SIC and sector-product cells. Again, levels differences between means and medians are substantial, suggesting the presence of outliers.

\section{4 / Employment}

Under Companies House rules, companies are only obliged to report employment data in specific cases: in our raw data, only 100,359 companies provide this information. As with revenue, this will be a selected sub-sample. We would expect companies with employees to be older and have higher revenues than those without, and this turns out to be the case: those in the employment 'set' are on average twice as old, and report average modelled revenues around 2/3 higher than the non-employment 'set'. These caveats should be borne in mind in what follows. On the other hand, tests of industrial structure suggest very similar shares of ICT and non-ICT companies and the spatial distribution of the companies across the UK is very similar, with three out of the top five locations being shared.

\section{Table 11 about here}

First we look at employees per firm. Table 11 shows average and median employees per company. As not all companies report employment in every year, we smooth the data across three and five-year periods. Average employment counts for ICT businesses differ substantially between SIC and Gi-based definitions. Using SIC codes, non-ICT businesses are somewhat larger and ICT firms, and a little bigger than the average firms. Using sectorproduct definitions, ICT firms employ rather more people on average than companies in the wider economy and the average firm, especially in the 2008-2012 period. However, median differences are much smaller, with non-ICT firms consistently reporting higher worker counts. That suggests outliers explain much of the mean differences.

\section{Table 12 about here}


Next, we turn to ICT firms' share of all employment (for which we have information). Table 12 shows that shifting from SIC-based definitions of digital businesses to Gi definitions shifts ICT firms' employment share substantially upwards, from around $3.5 \%$ to nearly $12 \%$ of all jobs in $2008-2012$, and from $3.7 \%$ to $8.92 \%$ in $2010-12$. This is as we would expect, since underlying company counts are higher in our big data-driven definitions.

\section{8 / Discussion}

This paper uses innovative 'big data' resources to perform an alternative analysis of the digital economy, focusing on ICT producing firms in the UK (so-called 'information economy' businesses). Exploiting a combination of public, observed and modelled variables, we develop careful cleaning routines and develop a novel 'sector-product' mapping approach, using text mining to provide further detail. We argue that this can provide advantages over SIC codes and conventional datasets, which tend to lag rapidly evolving real-world features of these industries.

Our big data-driven estimates suggest that the count of information economy firms is around 42\% larger than SIC-based estimates, with almost 70,000 more companies. We also find employment shares over double the conventional estimates, although this result is more speculative. The largest sector-product cells are in information technology (sectors) and consultancy (products); text analysis suggests software, Internet tools, system management and business / finance are particular strengths of companies in these cells. More broadly, ICT hardware, games, ICT-related engineering/manufacturing, telecoms, care and maintenance are key activities across the UK's ICT production activity space. ICT firms are slightly younger than non-ICT firms, with a slightly higher share of start-ups; while their average revenues are lower, on some measures revenue growth for ICT firms is higher than for their non-ICT counterparts. Defined on a sector-product basis, ICT firms employ more people on average than non-ICT firms (although median differences are much smaller).

We thus find a set of companies that is larger, more established and perhaps more resilient than popular perceptions. Our analysis also suggests diffusion of digital platforms and products out of computer hardware and software into other parts of the economy, notably business services and engineering / high-end manufacturing. This is consistent with specific 
industry studies (see e.g. Nathan and Vandore (Forthcoming)), and supports our case that big data can shine a light on real-world economic shifts that are moving ahead of current administrative data and classifications.

Our results are robust to multiple validation of the core dataset and a series of robustness checks. Some care has to be taken with the revenue and employment findings, since these derive from non-random sub-samples, but $\mathrm{Gi}$ is able to provide some workarounds for these (such as modelled revenue).

Our experiences so far with the Growth Intelligence dataset also provides us with some valuable lessons on the pros and cons of using 'frontier' data for innovation research. Gi data has excellent reach and granularity and, as we have shown, provides rich detail on fastchanging parts of the economy. However, like other commercial products such as FAME, the Gi dataset is not free to academic researchers and there is no automatic right to access. Similarly, Gi's proprietary layers are based on non-public code, ultimately limiting what validation can be done. This may limit wider replicability of the results by other teams and in other country contexts. These constraints are not unique to big data, however.

Other issues derive directly from the use of core big data tools and analytics. Web and newsbased information on companies is extremely rich but is not always comprehensive, and needs to be supplemented from other sources. Data providers may throttle data drawn from APIs, which places some constraints on speed of draw-down and thus the 'real-time' character of some unstructured sources: in some such cases, paying for direct access to the full dataset may be a more sensible solution. At a more basic level, the use of learning routines to generate probabilistic variables is ideal for exploring aggregate patterns in very large datasets, but can become noisy when researchers wish to look at smaller blocs of the data, or when they are working with relatively few observations to start with. In this case, we shifted to using raw data for small-cell analysis.

Together, these imply broader issues for researchers and policymakers. First, researchers should carefully consider the advantages and limitations of 'off the shelf' big datasets, and consider developing their own bespoke information as a complement. Second, government and universities need to develop researcher capacity to generate, as well as analyse, unstructured and other frontier data resources. Third, there is a clear need for secure sharing 
environments where proprietary and public data can be pooled, explored and validated. In the UK, the Secure Data Service provides one potential model for such platform. Finally, and linked to this, there is a need for structured partnership projects to incentivise researchers and data providers to work together.

We suggest various avenues for future research. One is exploring co-location and clusters. Another is to use modelled events as predictors of future observed behaviour. A third is to look at determinants of growth or lifecycle events. In the last two cases, the analysis would need to be done for the sub-sample of companies that can be 'panellised' in the data, and would benefit from merging with administrative datasets. More broadly, this company-level data could be combined with worker-level information to explore how ICTs are changing patterns of labour use and workforce organisation. 
Table 1. ICT products and services. List of SIC2007 codes.

\begin{tabular}{|c|l|}
\hline \multicolumn{1}{|c|}{ ICT manufacturing } \\
\hline $\mathbf{2 6}$ & Manufacture of computer, electronic and optical products \\
26110 & Manufacture of electronic components \\
26120 & Manufacture of loaded electronic boards \\
26300 & Manufacture of computers and peripheral equipment \\
26309 & Manufacture of telegraph and telephone apparatus and equipment \\
26400 & Manufacture of other communication equipment \\
26511 & Manufacture of consumer electronics \\
26512 & process control \\
26513 & Manufacture of electronic process control equipment \\
26514 & Manufacture of non-electronic measuring, testing equipment \\
26701 & Manufacture of optical precision instruments \\
26702 & Manufacture of photographic and cinematographic equipment \\
26800 & Manufacture of magnetic and optical media \\
\hline \multicolumn{2}{|c|}{ ICT services } \\
\hline $\mathbf{5 8}$ & Publishing activities \\
58210 & Publishing of computer games \\
58290 & Other software publishing \\
\hline $\mathbf{6 1}$ & Telecommunications \\
61100 & Wired telecommunications activities \\
61200 & Wireless telecommunications activities \\
61300 & Satellite telecommunications activities \\
61900 & Other telecommunications activities \\
\hline $\mathbf{6 2}$ & Computer programming, consultancy and related activities \\
62011 & Ready-made interactive leisure and entertainment software \\
62012 & Business and domestic software development \\
62020 & IT consultancy activities \\
62030 & Computer facilities management activities \\
62090 & Other information technology service activities \\
\hline $\mathbf{6 3}$ & Information service activities \\
63110 & Data processing, hosting and related \\
\hline
\end{tabular}

Source: OECD (2011), BIS (2013) authors' adjustments.

Notes: We follow the core definitions in OECD (2011) but use 5-digit not 4-digit SIC codes. In consultation with BIS we make minor adjustments for the UK context at 5-digit level: we remove 71121 and 71122 but include 62030. Following BIS (2013) we also separate out ICT services and manufacturing groups. 
Table 2. ICT producer counts and shares: comparing SIC and big data estimates.

\begin{tabular}{|c|c|c|}
\hline & Companies & $\%$ \\
\hline \multicolumn{3}{|c|}{ A. SIC 07 - manufacturing and services } \\
\hline Other & $1,783,973$ & 91.83 \\
\hline Information Economy & 158,810 & 8.17 \\
\hline \multicolumn{3}{|c|}{ B. Gi sector and product - manufacturing and services } \\
\hline Other & $1,716,983$ & 88.38 \\
\hline Information Economy & 225,800 & 11.62 \\
\hline \multicolumn{3}{|c|}{ "C1. SIC 07 - ICT services only } \\
\hline Other & $1,789,405$ & 92.11 \\
\hline Information Economy & 153,368 & 7.89 \\
\hline \multicolumn{3}{|c|}{ C2. Gi - ICT services only } \\
\hline Other & $1,761,811$ & 90.68 \\
\hline Information Economy & 180,972 & 9.32 \\
\hline \multicolumn{3}{|c|}{ D1. SIC 07 - services, manufacturing \& supply chain } \\
\hline Other & $1,748,607$ & 90.01 \\
\hline Information Economy & 194,176 & 9.99 \\
\hline \multicolumn{3}{|c|}{ D2. Gi - services, manufacturing \& supply chain } \\
\hline Other & $1,708,549$ & 87.94 \\
\hline Information Economy & 234,234 & 12.06 \\
\hline \multicolumn{3}{|l|}{ E. Gi sector } \\
\hline Other & $1,637,606$ & 84.29 \\
\hline Information Economy & 305,177 & 15.71 \\
\hline \multicolumn{3}{|c|}{ F. Gi sector and product - manufacturing and services $(0.3 \%$ threshold) } \\
\hline Other & $1,744,303$ & 89.78 \\
\hline Information Economy & 198,480 & 10.22 \\
\hline \multicolumn{3}{|c|}{ G. Gi sector and product - manufacturing and services (0.5\% threshold) } \\
\hline Other & $1,749,376$ & 90.04 \\
\hline Information Economy & 193,407 & 9.96 \\
\hline Total / panel & $1,942,783$ & 100 \\
\hline
\end{tabular}

Source: Gi and Companies House data

Note: In Panel A, SIC-defined information economy includes sectors as reported in Table 1. Other includes all the other firms. Panel B defines the information economy using Gi ICT sector by ICT product "cells", starting from the initial SIC category including both ICT services and manufacturing. Panel C defines the information economy using SIC "cells", starting from the initial SIC category including only ICT services. Panel D defines the information economy using SIC "cells" including ICT services, manufacturing and supply chain sectors. Panel E shows the count if the information economy was only defined using Gi ICT sectors. Panel $F$ and $G$ use different threshold rules to identify Gi ICT products and sectors. 
Table 3. SIC codes for 'additional' ICT producer companies, 16 largest cells.

\begin{tabular}{|c|c|c|c|}
\hline Description & SIC2007 & Observations & $\%$ \\
\hline $\begin{array}{l}\text { Other engineering activities (not including engineering design for industrial process and } \\
\text { production }\end{array}$ & 71129 & 12,520 & 17 \\
\hline Advertising agencies & 73110 & 9,166 & 12 \\
\hline Specialised Design Activities & 74100 & 7,596 & 10 \\
\hline Engineering related scientific and technical consulting activities & 71122 & 4,872 & 6.5 \\
\hline Technical testing and analysis & 71200 & 2,982 & 4 \\
\hline Repair of other equipment & 33190 & 2,918 & 3.9 \\
\hline Engineering design activities for industrial process and production & 71121 & 2,874 & 3.8 \\
\hline Other business support service activities n.e.c. & 82990 & 2,583 & 3.4 \\
\hline Manufacture of electric motors, generators and transformers & 33140 & 1,924 & 2.6 \\
\hline Repair of machinery & 33120 & 1,849 & 2.5 \\
\hline Installation of industrial machinery and equipment & 33200 & 1,845 & 2.4 \\
\hline Repair of computers and peripheral equipment & 95110 & 1,778 & 2.4 \\
\hline Wholesale of electronic and telecommunications equipment and parts & 46520 & 1,605 & 2.1 \\
\hline Manufacture of other electrical equipment & 27900 & 1,424 & 1.9 \\
\hline Activities of head offices & 70100 & 1,132 & 1.5 \\
\hline Electrical installation & 43210 & 1,115 & 1.5 \\
\hline Management consultancy activities (other than financial management) & 70229 & 819 & 1.1 \\
\hline Retail sale of computers, peripheral units and software in specialised stores & 47410 & 773 & 1 \\
\hline
\end{tabular}

Source: Gi and Companies House data

Note: Firms in the information economy (Gi definition) but not in the SIC code definition. The percentage refers to the percentage of firms captured using Gi definition in each SIC code excluded from the official definition (only the most relevant are reported). The information economy is defined using Gi sectors and products. 
Table 4: Total number of firms in the information economy by Gi sectors

\begin{tabular}{lcccc} 
& & & \multicolumn{2}{c}{ Revenues } \\
\hline & Observations & $\%$ & mean & median \\
\hline computer_games & 2,585 & 1.14 & 1793241 & 3181.5 \\
computer_hardware & 3,514 & 1.56 & 2473394.4 & 83803 \\
computer_networking & 3,902 & 1.73 & 2135848.7 & 93784 \\
computer_network_security & 226 & 0.1 & 13223530 & 1027628 \\
computer_software & 23,455 & 10.39 & 1433080.5 & 35564 \\
consumer_electronics & 2,074 & 0.92 & 11125476 & 97584 \\
design & 10,049 & 4.45 & 753104.63 & 53798.5 \\
e_learning & 347 & 0.15 & 4496422.4 & 320504.5 \\
electrical_electronic_manufacturing & 17,319 & 7.67 & 3696466.6 & 93784 \\
information_services & 823 & 0.36 & 5018562.8 & 182405 \\
information_technology & 104,768 & 46.4 & 995039.69 & 38364 \\
internet & 2,954 & 1.31 & 6527924.2 & 195958 \\
marketing_advertising & 11,038 & 4.89 & 3695790.4 & 42077 \\
mechanical_or_industrial_engineering & 27,326 & 12.1 & 1145004.3 & 93784 \\
semiconductors & 183 & 0.08 & 64762995 & 1323417 \\
telecommunications & 15,237 & 6.75 & 16347362 & 78165 \\
Total & 225,800 & 100 & $2,723,804$ & 57,282 \\
\hline
\end{tabular}

Source: Gi and Companies House data

Note: Observations by sector when defining digital economy using Gi ICT products and sectors (manufacturing and services). Revenues are Gi modelled revenues. 
Table 5: Total number of firms in the information economy by Gi product

\begin{tabular}{lcccc} 
& \multicolumn{3}{c}{ Revenues } \\
\cline { 2 - 5 } & Observations & $\%$ & mean & median \\
\hline advertising_network & 1,663 & 0.74 & $3,163,943$ & 341,687 \\
broadband_services & 8,628 & 3.82 & $4,050,860$ & 18,369 \\
care_or_maintenance & 15,663 & 6.94 & $1,300,043$ & 54,642 \\
consultancy & 151,408 & 67.05 & $2,009,348$ & 57,802 \\
education_courses & 645 & 0.29 & $6,321,385$ & 434,989 \\
electronics & 15,180 & 6.72 & $12,953,757$ & 174,866 \\
peer_to_peer_communications & 1,300 & 0.58 & $13,120,439$ & 0 \\
software_desktop_or_server & 5,237 & 2.32 & 547,854 & 13,171 \\
software_mobile_application & 31 & 0.01 & $2,953,207$ & $1,426,606$ \\
software_web_application & 43 & 0.02 & $14,577,145$ & 409,863 \\
custom_software_development & 19,981 & 8.85 & $1,012,336$ & 34,814 \\
web_hosting & 6,021 & 2.67 & $1,392,615$ & 34,765 \\
Total & 225,800 & 100 & $2,723,804$ & 57,282 \\
\hline Source:Ciand & & & &
\end{tabular}

Source: Gi and Companies House data

Note: observations by product when defining digital economy using Gi ICT products and sectors ((manufacturing and services). Revenues are Gi modelled revenues. 
Table 6. Word distribution within sectors

\begin{tabular}{|c|c|c|c|c|c|c|c|c|}
\hline & \multicolumn{2}{|c|}{ A. ICT MF and services } & \multicolumn{2}{|c|}{ B. IT \& consultancy } & \multicolumn{2}{|c|}{ C. Consultancy } & \multicolumn{2}{|l|}{ D. IT } \\
\hline & words appearances & $\begin{array}{c}\text { relative } \\
\text { share }\end{array}$ & words appearances & $\begin{array}{c}\text { relative } \\
\text { share }\end{array}$ & words appearances & $\begin{array}{c}\text { relative } \\
\text { share }\end{array}$ & words appearances & $\begin{array}{c}\text { relative } \\
\text { share }\end{array}$ \\
\hline technology & 70,139 & $4 \%$ & 13,874 & $7 \%$ & 37,708 & $5 \%$ & 16,002 & $6 \%$ \\
\hline software & 66,063 & $4 \%$ & 13,767 & $7 \%$ & 35,036 & $4 \%$ & 16,485 & $7 \%$ \\
\hline online & 54,668 & $3 \%$ & 7,106 & $4 \%$ & 26,175 & $3 \%$ & 8,465 & $3 \%$ \\
\hline internet & 49,843 & $3 \%$ & 6,114 & $3 \%$ & 21,090 & $3 \%$ & 7,423 & $3 \%$ \\
\hline management & 47,312 & $3 \%$ & 11,209 & $6 \%$ & 32,027 & $4 \%$ & 12,602 & $5 \%$ \\
\hline services & 43,136 & $2 \%$ & 9,658 & $5 \%$ & 27,194 & $3 \%$ & 10,701 & $4 \%$ \\
\hline technology_internet & 40,286 & $2 \%$ & 4,960 & $3 \%$ & 18,349 & $2 \%$ & 6,397 & $3 \%$ \\
\hline systems & 38,195 & $2 \%$ & 6,152 & $3 \%$ & 17,657 & $2 \%$ & 7,280 & $3 \%$ \\
\hline solutions & 33,726 & $2 \%$ & 7,599 & $4 \%$ & 20,273 & $2 \%$ & 8,816 & $4 \%$ \\
\hline business & 26,851 & $1 \%$ & 6,134 & $3 \%$ & 18,135 & $2 \%$ & 6,859 & $3 \%$ \\
\hline media & 26,474 & $1 \%$ & 3,073 & $2 \%$ & 15,083 & $2 \%$ & 3,835 & $2 \%$ \\
\hline business_finance & 25,406 & $1 \%$ & 3,581 & $2 \%$ & 15,603 & $2 \%$ & 4,028 & $2 \%$ \\
\hline search & 23,731 & $1 \%$ & 2,406 & $1 \%$ & 10,365 & $1 \%$ & 2,871 & $1 \%$ \\
\hline wireless & 23,018 & $1 \%$ & 2,032 & $1 \%$ & 7,007 & $1 \%$ & 2,858 & $1 \%$ \\
\hline solution & 22,178 & $1 \%$ & 4,678 & $2 \%$ & 12,647 & $2 \%$ & 5,557 & $2 \%$ \\
\hline mobile & 21,694 & $1 \%$ & 3,226 & $2 \%$ & 11,079 & $1 \%$ & 3,992 & $2 \%$ \\
\hline network & 20,883 & $1 \%$ & 3,656 & $2 \%$ & 11,435 & $1 \%$ & 4,275 & $2 \%$ \\
\hline computing & 20,540 & $1 \%$ & 5,251 & $3 \%$ & 10,746 & $1 \%$ & 6,214 & $3 \%$ \\
\hline design & 19,387 & $1 \%$ & 1,341 & $1 \%$ & 7,845 & $1 \%$ & 1,655 & $1 \%$ \\
\hline communications & 18,990 & $1 \%$ & 2,145 & $1 \%$ & 11,230 & $1 \%$ & 2,363 & $1 \%$ \\
\hline system & 18,911 & $1 \%$ & 2,727 & $1 \%$ & 7,998 & $1 \%$ & 3,663 & $1 \%$ \\
\hline service & 18,493 & $1 \%$ & 3,410 & $2 \%$ & 9,901 & $1 \%$ & 3,872 & $2 \%$ \\
\hline energy & 18,013 & $1 \%$ & 2,340 & $1 \%$ & 9,108 & $1 \%$ & 2,591 & $1 \%$ \\
\hline products & 17,627 & $1 \%$ & 2,192 & $1 \%$ & 7,179 & $1 \%$ & 2,590 & $1 \%$ \\
\hline applications & 17,477 & $1 \%$ & 2,977 & $2 \%$ & 7,603 & $1 \%$ & 3,593 & $1 \%$ \\
\hline marketing & 16,758 & $1 \%$ & 1,404 & $1 \%$ & 9,974 & $1 \%$ & 1,614 & $1 \%$ \\
\hline social & 16,033 & $1 \%$ & 2,384 & $1 \%$ & 9,507 & $1 \%$ & 2,753 & $1 \%$ \\
\hline server & 14,044 & $1 \%$ & 2,522 & $1 \%$ & 6,186 & $1 \%$ & 3,467 & $1 \%$ \\
\hline
\end{tabular}




\begin{tabular}{lcccccccc} 
technologies & 14,002 & $1 \%$ & 3,627 & $2 \%$ & 8,418 & $1 \%$ & 4,157 & $2 \%$ \\
digital & 13,656 & $1 \%$ & 1,274 & $1 \%$ & 5,877 & $1 \%$ & $1 \%$ & 1,618 \\
telephone & 13,574 & $1 \%$ & 0 & 0,135 & $8 \%$ & $1 \%$ & 4,552 \\
information & 13,263 & $1 \%$ & 3,957 & $2 \%$ & 8,748 & $2 \%$ \\
\hline Total & 884,371 & $48 \%$ & 146,776 & $74 \%$ & 463,318 & $57 \%$ & 174,358 \\
\hline
\end{tabular}

Source: Gi data

Note: Word appearance refers to the number of time the word appears in the sample of companies reporting token. Relative share is computed as the number of appearances over the total number of words in the sample. Panel A reports words in the tokens in all the companies in the information economy defined including both manufacturing and service sectors. Panel B reports the words in the tokens of the companies in IT (sector cell) and consultancy (product cell). Panel C companies doing consultancy. Panel D companies in the IT sector. 
Table 7. Age of companies, mean and median years of activity.

\begin{tabular}{lcccc}
\hline & \multicolumn{2}{c}{ Other } & \multicolumn{2}{c}{ Information Economy } \\
& mean & median & mean & median \\
\hline SIC 07 - manufacturing and services & 10.3 & 6.5 & 7.7 & 5.4 \\
GI sector and product & 10.3 & 6.5 & 8.4 & 5.7 \\
\hline
\end{tabular}

Source: Gi and Companies House data

Note: Age defined as years of activity since the company was incorporated

Table 8. Distribution of companies by age groups.

\begin{tabular}{lcc}
\hline & \multicolumn{2}{c}{$\%$} \\
\hline & Other & $\begin{array}{c}\text { Information } \\
\text { Economy }\end{array}$ \\
\hline $\begin{array}{l}\text { A. SIC 07 - manufacturing and } \\
\text { services }\end{array}$ & \\
up to 1 year old & 2.04 & 2.14 \\
up to 3 years & 13.71 & 16.33 \\
up to 5 years & 30.55 & 35.48 \\
up to 10 years & 64.57 & 67.31 \\
\hline B. GI sector and product & & \\
up to 1 year old & 2.18 & 1.00 \\
up to 3 years & 13.84 & 14.44 \\
up to 5 years & 30.66 & 33.06 \\
up to 10 years & 64.61 & 66.06 \\
\hline
\end{tabular}

Source: Gi and Companies House data

Note: Each entry represents the share of companies within each age group 
Table 9: Mean and median revenues and revenue growth from Companies House

A. Average Revenues

B. Average Annual Revenue Growth

\begin{tabular}{cccccccc} 
& \multicolumn{3}{c}{ A. Average Revenues } & \multicolumn{3}{c}{ B. Average Annual Revenue Growth } \\
\hline Companies House & \multicolumn{2}{c}{ Gi } & Obs & $\begin{array}{c}\text { sector } \\
\text { distribution }\end{array}$ & Companies House & Obs & sector \\
distribution
\end{tabular}

\begin{tabular}{|c|c|c|c|c|c|c|c|c|c|c|}
\hline \multirow{2}{*}{\multicolumn{11}{|c|}{$\begin{array}{c}\text { mean } \\
\text { SIC } 07 \text { - manufacturing and services }\end{array}$}} \\
\hline & & & & & & & & & & \\
\hline $\begin{array}{l}\text { Other } \\
\text { Information }\end{array}$ & $21,640,058$ & 125,281 & $25,780,253$ & 70,196 & 254,025 & 0.94 & 0.16 & 0.02 & 154,442 & 0.94 \\
\hline Economy & $11,658,404$ & 97,669 & $13,142,859$ & 83,073 & 17,593 & 0.06 & 0.23 & 0.05 & 9,402 & 0.06 \\
\hline \multicolumn{11}{|c|}{ GI sector and product } \\
\hline $\begin{array}{l}\text { Other } \\
\text { Information }\end{array}$ & $21,605,718$ & 124,241 & $25,864,831$ & 68,469 & 245,940 & 0.91 & 0.15 & 0.02 & 149,791 & 0.91 \\
\hline Economy & $15,130,138$ & 106,640 & $16,311,935$ & 91,240 & 25,678 & 0.09 & 0.22 & 0.05 & 14,053 & 0.09 \\
\hline
\end{tabular}

Source: Gi and Companies House data

Note: Companies House average revenues are averaged over the period 2010 to 2012. Gi revenues are computed over the same sample. For the Companies House dataset if for each company there is more than one observation, only the most recent is kept. Average annual revenue growth is computed on a smaller sample, as information for at least two consecutive years is need. The years considered are the same as above, 2010 to 2012. 
Table 10: Gi modelled revenues by sector

\begin{tabular}{lcccc}
\cline { 2 - 5 } & \multicolumn{4}{c}{ Gi (mean and median) revenues } \\
\hline & SIC 07 - manufacturing and & \multicolumn{2}{c}{ GI sector and product } \\
mean & medices & mean & median \\
\hline $\begin{array}{l}\text { Other } \\
\text { Information }\end{array}$ & $4,945,056$ & 45,975 & $4,948,276$ & 44,611 \\
Economy & $1,820,333$ & 47,071 & $2,723,804$ & 57,282 \\
\hline
\end{tabular}

Source: Gi and Companies House data

Note: Gi modelled revenues 
Table 11. Average employees per firm.

\begin{tabular}{llccccc}
\hline \multicolumn{1}{c}{ Breakdown } & Observations & & Gi & \multicolumn{2}{c}{ SIC codes } \\
Median
\end{tabular}

Notes: Sub-sample of companies filing employment information to Companies House

Table 12. ICT and non-ICT employment shares.

\begin{tabular}{lcc}
\hline Category & \multicolumn{2}{c}{$\begin{array}{c}\text { Share of all employment (\%) } \\
\mathbf{2 0 0 8 - 2 0 1 2}\end{array}$} \\
\hline & & $\mathbf{2 0 1 0 - 2 0 1 2}$ \\
Information economy (SIC codes) & 3.54 & 3.70 \\
Other & 96.46 & 96.30 \\
& & 8.92 \\
Information economy (Gi) & 11.75 & 91.08 \\
Other & 88.25 & \\
\hline
\end{tabular}

Notes: Sub-sample of companies filing employment information to Companies House 
Figure 1. Most frequent words in ICT producer activity space: web tokens.

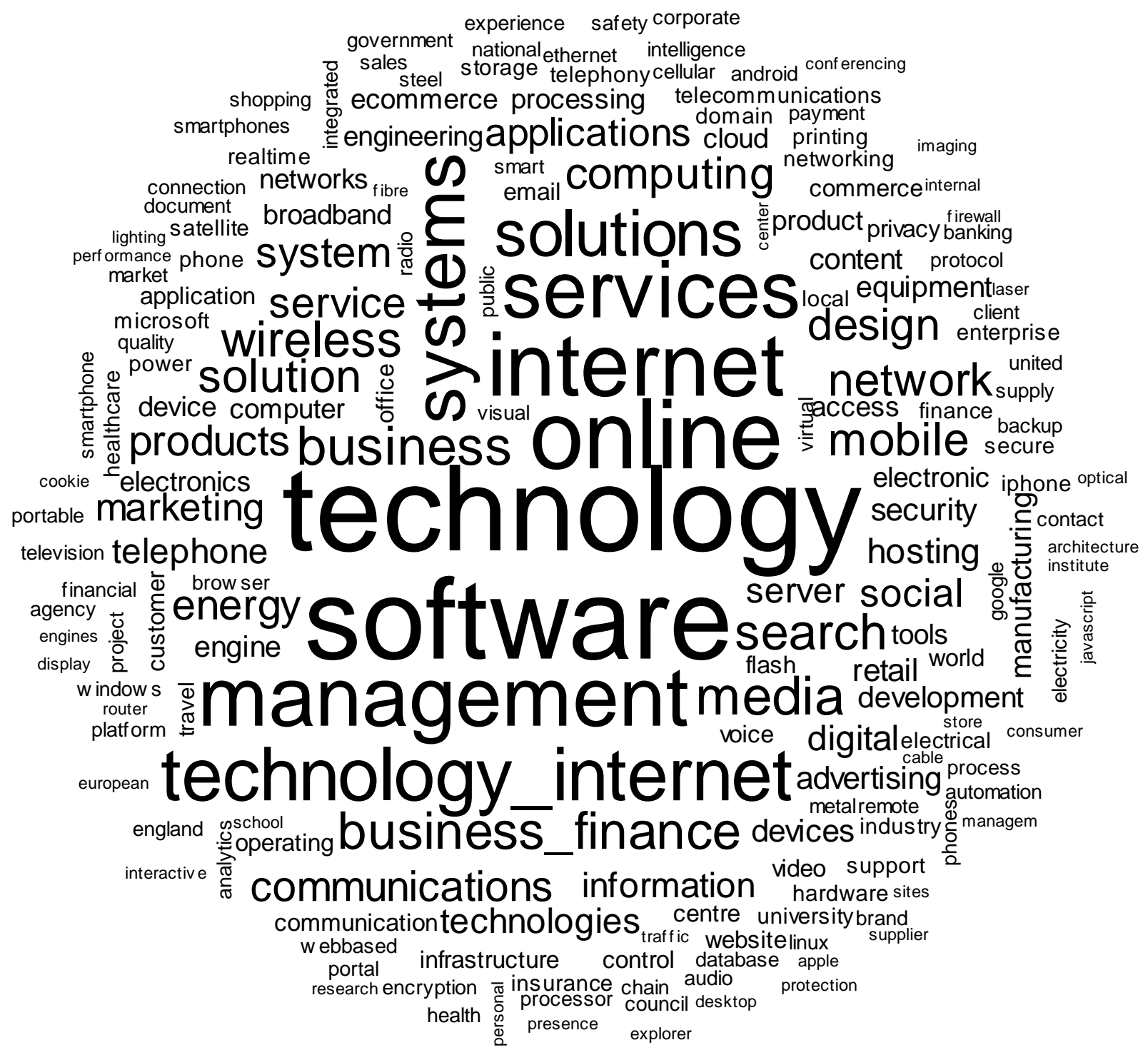

Source: Gi data 
Figure 2. Most frequent words in the rest of the economy: web tokens.

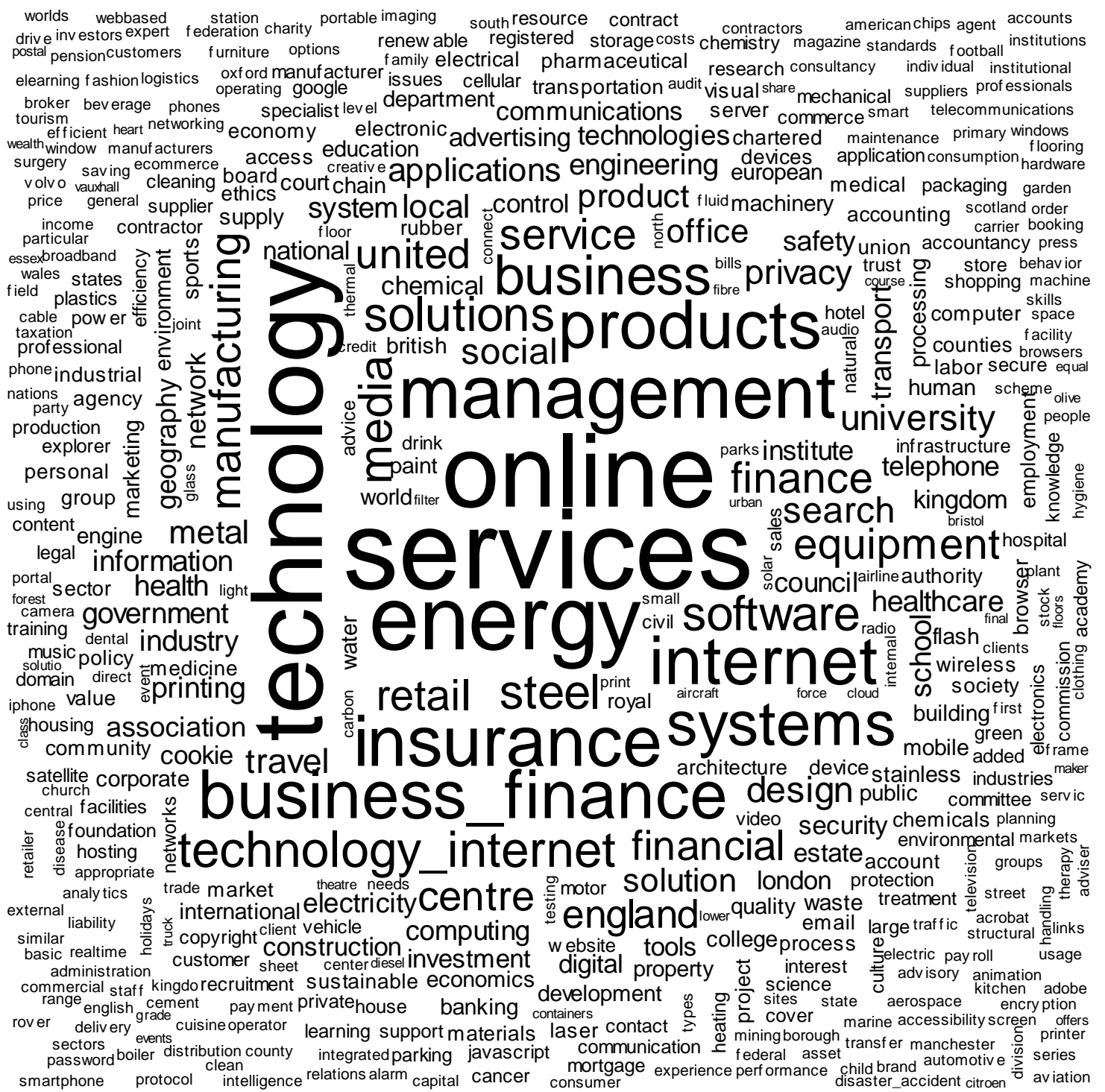

Source: Gi data 
Figure 3. Inflow of companies between 1991 and 2011

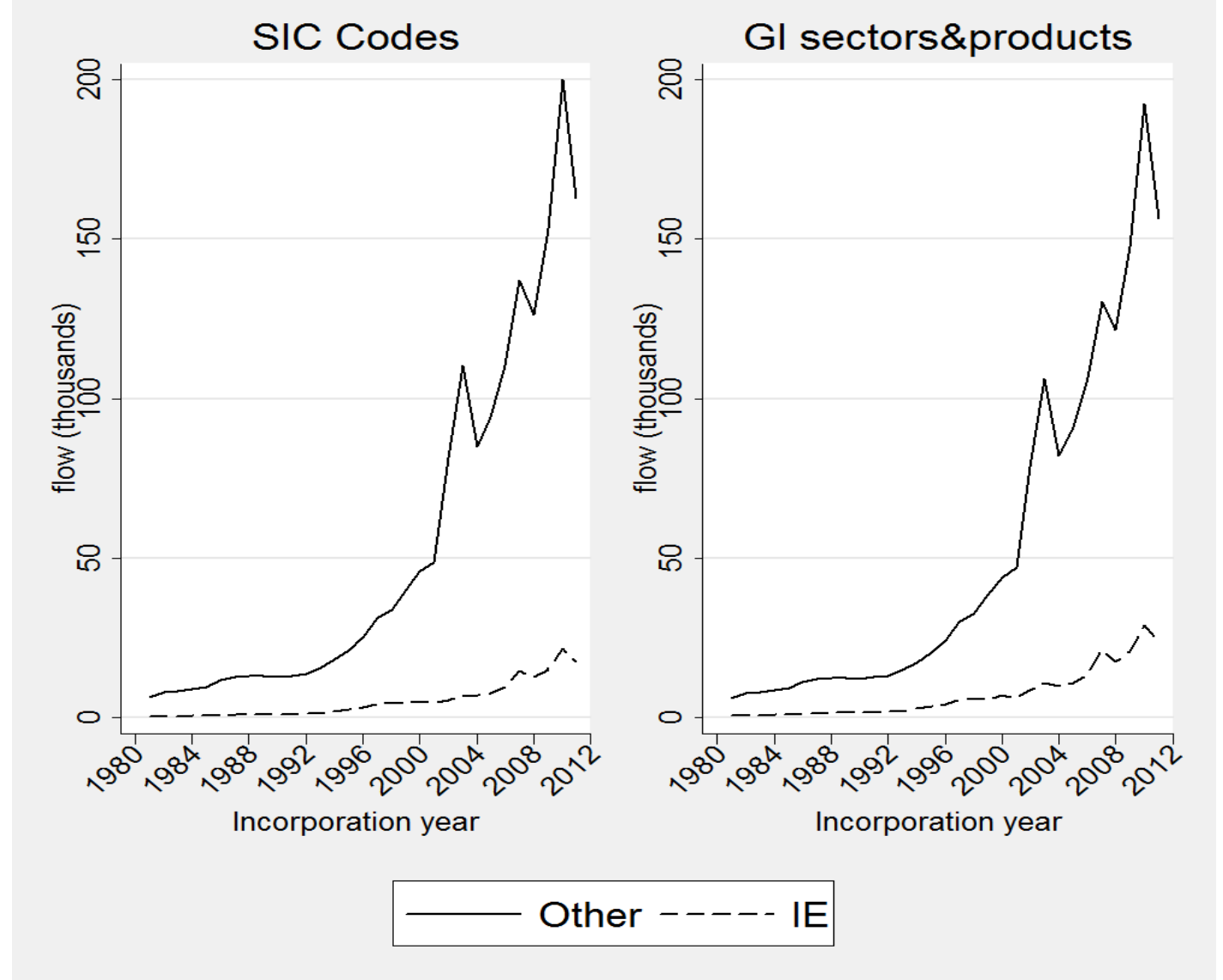

Source: Gi and Companies House data

Note: The graphs show the inflow of active companies in each year 
Figure 4: Growth rate in the number of firms between 1980 and 2011
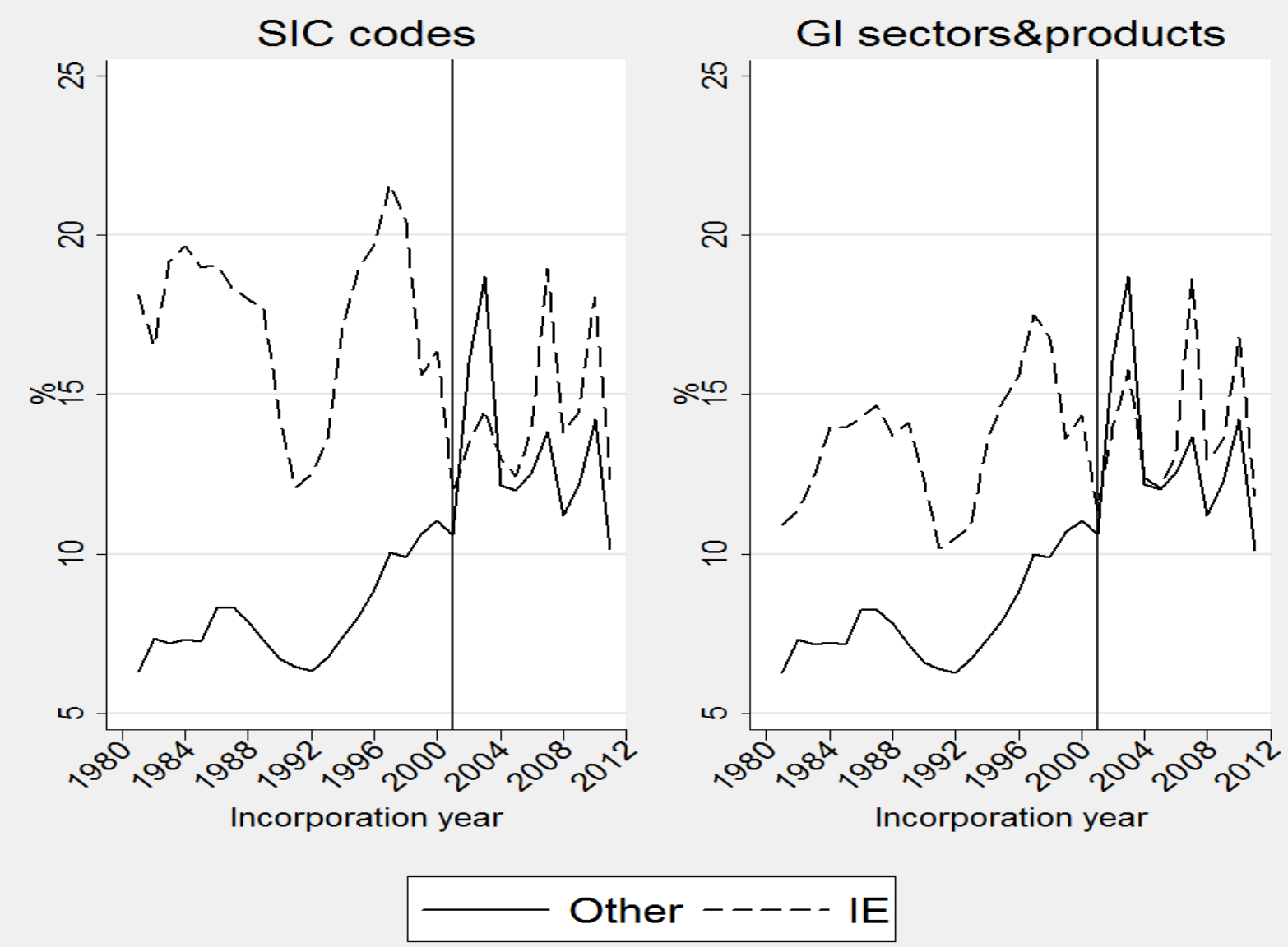

Source: Gi and Companies House data Note: Growth rate as a percentage of number of firms entering the economy each year over the total existing firms 


\section{Acknowledgements}

This paper is based on research projects funded by Google and by NESTA. Many thanks to Francois Bouet, Tom Gatten, Prash Majmudar and Alex Mitchell at Growth Intelligence for data, and help with its preparation and interpretation. For advice and helpful comments, thanks also to Hasan Bakhshi, Theo Bertram, Siobhan Carey, Steve Dempsey, Juan MateosGarcia, Jonathan Portes, Rebecca Riley, Chiara Rosazza-Bondibene, Brian Stockdale, Dominic Webber and Stian Westlake plus participants at Birmingham University, Google, RSA, Imperial College, NARSC, NIESR, NESTA, NEMODE and TechUK workshops. Thanks also to Martin Kenney, Maryann Feldman, Francesco Lissoni and two anonymous referees. This work includes analysis based on data from the Business Structure Database, produced by the Office for National Statistics (ONS) and supplied by the Secure Data Service at the UK Data Archive. The data is Crown copyright and reproduced with the permission of the controller of HMSO and Queen's Printer for Scotland. The use of the ONS statistical data in this work does not imply the endorsement of the ONS or the Secure Data Service at the UK Data Archive in relation to the interpretation or analysis of the data. This work uses research datasets that may not exactly reproduce National Statistics aggregates. All the outputs have been granted final clearance by the staff of the SDS-UKDA. The paper gives the views of the authors, not the funders or the data providers. Any errors and omissions are our own. 


\section{References}

Aghion, P., Besley, T., Browne, J., Caselli, F., Lambert, R., Lomax, R., Pissarides, C., Van Reenen, J., 2013. Investing for Prosperity: Skills, Infrastructure and Innovation, Report of the LSE Growth Commission. Centre for Economic Performance / Institute for Government, London.

Aiginger, K., 2007. Industrial Policy: A Dying Breed or A Re-emerging Phoenix. Journal of Industry, Competition and Trade 7, 297-323.

Anyadike-Danes, M., 2011. Aston University matching of BSD and FAME data: report to BIS. Aston Business School, Birmingham.

Askitas, N., Zimmermann, K.F., 2009. Google Econometrics and Unemployment Forecasting. Applied Economics Quarterly (formerly: Konjunkturpolitik) 55, 107-120.

Audretsch, D., Feldman, M., 1996. R\&D Spillovers and the Geography of Innovation and Production. American Economic Review 86, 630-640.

Bakhshi, H., Mateos-Garcia, J., 2012. The Rise of the Datavores. NESTA, London.

Baron, A., Rayson, P., Archer, D., 2009. Word frequency and key word statistics in historical corpus linguistics. Anglistik: International Journal of English Studies 20, 41-67.

Block, F., Keller, M., 2011. State of Innovation: The US Government's Role in Technology Development. Paradigm, Boulder, CO.

Bloom, N., Sadun, R., Van Reenen, J., 2012. Americans Do IT Better: US Multinationals and the Productivity Miracle. American Economic Review 102, 167-201.

Bresnahan, T.F., Brynjolfsson, E., Hitt, L.M., 2002. Information Technology, Workplace Organization, and the Demand for Skilled Labor: Firm-Level Evidence. The Quarterly Journal of Economics 117, 339-376.

Cable, V., 2012. Industrial Strategy, Speech to Imperial College London, London.

Choi, H., Varian, H., 2012. Predicting the Present with Google Trends. Economic Record 88, 2-9.

Couture, V., 2013. Valuing the Consumption Benefits of Urban Density, mimeo. University of Toronto, Toronto.

Department for Business Innovation and Skills, 2012. Industrial Strategy: UK sector analysis. BIS, London.

Department for Business Innovation and Skills, 2013. Information Economy Strategy. BIS, London.

Di Lorenzo, G., Reades, J., Calabrese, F., Ratti, C., 2012. Predicting personal mobility with individual and group travel histories. Environment and Planning B: Planning and Design 39, 838-857.

Dittmar, J.E., 2011. Information Technology and Economic Change: The impact of the printing press. The Quarterly Journal of Economics 126, 1133-1172.

Einav, L., Levin, J.D., 2013. The Data Revolution and Economic Analysis, National Bureau of Economic Research Working Paper Series No. 19035. NBER, Cambridge, MA. 
Fetzer, T., 2014. Measuring Legislator Productivity: A New Approach, mimeo. LSE, London.

Foord, J., 2013. The new boomtown? Creative city to Tech City in east London. Cities 33, 51-60.

Gentzkow, M., Shapiro, J.M., 2010. What Drives Media Slant? Evidence From U.S. Daily Newspapers. Econometrica 78, 35-71.

Ginsberg, J., Mohebbi, M.H., Patel, R.S., Brammer, L., Smolinski, M.S., Brilliant, L., 2009. Detecting influenza epidemics using search engine query data. Nature 457, 1012-1014.

Harrison, A., Rodríguez-Clare, A., 2009. Trade, Foreign Investment, and Industrial Policy for Developing Countries, National Bureau of Economic Research Working Paper Series No. 15261. NBER, Cambridge, MA.

Hastie, T., Tibshirani, R., Friedman, J., 2009. The Elements of Statistical Learning: Data mining, inference and prediction. Springer, Berlin.

King, G., 2013. Restructuring the Social Sciences: Reflections from Harvard's IQSS. Institute for Quantitative Social Science, Cambridge, Mass.

Lehr, W., 2012. Measuring the Internet: The Data Challenge, OECD Digital Economy Papers 194. OECD, Paris.

Lewis, P., Newburn, T., Taylor, M., McGillivary, C., 2011. Reading the Riots: Investigating England's summer of disorder. LSE / The Guardian, London.

Lucas, R., 1988. On the Mechanics of Economic Growth. Journal of Monetary Economics $22,3-42$.

Mazzucato, M., 2011. The Entrepreneurial State. Demos, London.

Moretti, E., 2012. The New Geography of Jobs. Haughton Mifflin Harcourt, Boston.

Nathan, M., Overman, H., 2013. Agglomeration, clusters, and industrial policy. Oxford Review of Economic Policy 29, 383-404.

Nathan, M., Rosso, A., 2013. Mapping the Digital Economy with Big Data. NIESR, London.

Nathan, M., Vandore, E., Forthcoming. Here Be Startups: Exploring a young digital cluster in Inner East London. Environment and Planning A.

Negroponte, N., 1996. Being Digital. Vintage, London.

OECD, 2011. OECD Guide to Measuring the Information Society 2011. OECD, Paris.

OECD, 2013. Measuring the Internet Economy: A contribution to the research agenda, OECD Digital Economy Papers 226. OECD Publishing.

Office of National Statistics, 2009. UK Standard Industrial Classification of Economic Activities 2007 (SIC 2007): Structure and explanatory notes. Palgrave Macmillan, Basingstoke.

Office of National Statistics, 2010. Business Structure Database: User Guide Social and Economic Micro Analysis Reporting Division, Office for National Statistics, Newport. Office of National Statistics, 2012. Guide to the Business Population and Demographic Statistics Publications. ONS, Newport. 
Rajaraman, A., Ullman, J.D., 2011. Data Mining: Mining of Massive Datasets. Cambridge University Press, Cambridge.

Rodrik, D., 2004. Industrial Policy for the Twenty-First Century, CEPR Discussion Paper 4767. Centre for Economic Policy Research, London.

Romer, P., 1990. Endogenous Technological Change. Journal of Political Economy 98, 71102.

Salton, G., Buckley, C., 1988. Term-weighting approaches in automatic text retrieval. Information Processing \& Management 24, 513-523.

Tapscott, D., 1997. The Digital Economy: Promise and peril in the age of networked intelligence. McGraw-Hill, New York.

Varian, H.R., 2014. Big Data: New Tricks for Econometrics. Journal of Economic Perspectives 28, 3-28. 


\section{ONLINE APPENDICES}

\section{Appendix A / The Growth Intelligence dataset}

Growth Intelligence (Gi) is a London-based company, founded in 2011, that provides business intelligence services to largely private sector clients. The Gi dataset combines public administrative data, structured data and modelled data derived from unstructured sources. The dataset is best described in terms of layers.

\section{A1 / Companies House layer}

The 'base layer' of the Gi dataset comprises all active companies in the UK, which is taken from the Companies House API and updated daily. Under the Companies Act 2006, all limited companies in the UK, and overseas companies with a branch or place of business in the UK need to be registered with Companies House. ${ }^{19}$ Some business partnerships (such as Limited Liability Partnerships) also need to register. There is a charge of around $£ 100$ to do this. Sole traders and business partnerships which are not LLPs do not need to register at Companies House, although they will need to file tax returns with HMRC. When they register, companies are asked to choose the Standard Industrial Classification (SIC) code which best reflects their principal business activity. Dormant and non-trading companies are also asked to include SIC information.

All registered companies must file a) annual company returns as well as b) annual financial statements (statutory accounts). Returns cover details of directors and company secretary, registered office address, shares and shareholders, as well as company type and principal business activity. There is a small charge for filing the return, which must be done within 28 days of the anniversary of incorporation. There are financial penalties for not filing the return on time: in the extreme Companies House can dissolve the company and prosecute the directors. Statutory accounts must be filed with Companies House, in addition to tax returns with HMRC. Accounts must include a balance sheet, a profit and loss account, a directors'

\footnotetext{
${ }^{19}$ See www.companieshouse.gov.uk for more information
} 
report and an auditors' report. The balance sheet shows the value of company assets; the profit and loss accounts shows sales, running costs and subsequent profit / loss. Accounts must be compiled by nine months after the end of the financial year. As with returns, there are financial penalties for late filing, and possible criminal penalties for non-filing.

A number of companies are exempted from full filing. Limited companies that are 'small' can send abbreviated accounts consisting only of the balance sheet, and in some cases can apply for exemption from auditing. Small firms must meet two or more of the following: less than $£ 6.5 \mathrm{~m}$ turnover; less than $£ 3.26 \mathrm{~m}$ on the balance sheet; fewer than 50 employees. Some 'dormant' limited companies can also claim partial or full exemption from filing. Dormant companies are those defined as having no 'significant accounting transactions' during the accounting period in question.

Companies must inform Companies House about changes to limited companies, including directors / secretaries joining or leaving; changes to the company name, registered address or accounting dates, and where records are kept. Limited companies can request to be closed / dissolved, providing they have not traded within the last three months; not changed company name within that period; are not subject to current / proposed legal proceedings, and have not made a disposal for value of property or rights. There is a $£ 10$ charge for the striking off application. Once Companies House has accepted the application, a notice is placed in the London / Edinburgh / Belfast Gazette giving at least three months' notice of the intent to remove the company from the Register.

Companies are legal entities, and company-level observations may not always reflect the actual underlying business. We perform a number of cleaning steps to recover 'true' enterprises. These steps are discussed in detail in Section 4 of the main paper.

\section{A2 / Structured data layers}

Gi matches Companies House data to a series of other structured administrative datasets. Gi uses these structured datasets in two ways: to provide directly observed information on company activity (for example, patenting), and as an input for building modelled information 
about companies (for example, text from patent titles as an input to company sector / product classifications). We discuss these modelled data layers below.

\section{A3 / Modelled data layers}

This part of the Gi dataset is developed through data mining (Rajaraman and Ullman, 2011). Gi develops a range of raw text inputs for each company, and then uses feature extraction to identify key words and phrases ('tokens'), as well as contextual information ('categories'). ${ }^{20} \mathrm{Gi}$ assigns weights to these 'tokens' based on likelihood of identifying meaningful information about the company. Machine learning approaches are then used to develop classifications of companies by sector and product type, predicted lifecycle 'events' and modelled company revenue. Tokens, categories and weights are used as predictors, alongside observed information from the Companies House and structured data layers.

Tokens and token categories are extracted from a range of textual sources, including company websites, news media and news feeds, blogs, plus patents and trademarks text fields. In the language of text analysis, these 'documents' form a complete 'corpus' about the universe of companies (Baron et al., 2009). Growth Intelligence use an approach based on Text Frequency-Inverse Document Frequency (TF-IDF) weights to identify the most distinctive words in each company's document set. ${ }^{21}$ Informally, a given word will have a high TF-IDF for a given company if it a) appears in relatively few documents across the corpus, and b) appears many times when present in a given document.

For company classifications, Gi uses a supervised learning setting (see Hastie et al (2009) for an overview of these approaches). The basic idea is to take a randomly sampled training set of observations where classifications are known, then use this to develop a machine-learnt algorithm that can accurately predict company type on the basis of observed information (but

\footnotetext{
${ }^{20} \mathrm{Gi}$ uses multiple techniques for matching online information to companies, including direct matches from web URLs; whois records, and Companies House numbers reported on websites.

${ }^{21}$ The TF-IDF approach is the workhorse method in the field (Salton and Buckley, 1988); an alternative is to use the Pearson chi $^{2}$ score (see Gentzkow and Shapiro (2010) for a recent example).
} 
where classification is not known). Once validated on another random subsample, the tool is then used to classify the rest of the data.

Modelled revenue is generated using a machine-learnt regression. In this case reported revenue in Companies House data is used in the training set, with predictors drawn from other observed financial information, events and sector classification. 


\section{Appendix B / Comparing Companies House and BSD structures}

The benchmarking exercise in this paper involves taking raw Companies House $(\mathrm{CH})$ data and cleaning it to produce 'quasi-enterprises'. We need to be confident that our estimates are accurate. To do this, we validate the level and structure of our data against the main UK administrative source, the Business Structure Database (BSD). Information in the BSD is extremely reliable and is checked against multiple sources (ONS 2013). Firms enter the BSD when they have at least one employee on the payroll and/or have revenues high enough to charge VAT (sales tax). We look at levels and shares of SIC5 cells in $\mathrm{CH}$ and the BSD, across all sectors and for the 'information economy'.

There are a number of issues we need to test. First, our own cleaning steps may produce inaccuracies; in the main paper we run through a series of sensitivity tests on these. Second, the Companies House sampling frame may produce some structural peculiarities: legal entities are not necessarily active enterprises, and in sectors with low entry barriers (such as many parts of the information economy) we may see higher numbers than in the BSD. Our cleaning steps remove inactive companies so should mitigate this, but some underlying structural differences may persist. These reflect real characteristics of firms and industries, but we need to understand their nature. Third, Companies House processes may produce structural inaccuracies, particularly as firms assign themselves to an SIC code. Newly registering companies are - in most cases - very young, so may not understand the SIC system and/or fully know their main activity yet. This may lead companies to file in specific categories other than their 'true' categories. Specifically, companies might be more likely to file in uninformative 'not elsewhere classified' type SIC cells. The information economy set of SICs contains a number of these, which may bias up counts. Alternatively, companies may not provide SIC information at all. This plausibly affects companies with novel products and services, such as information economy firms, and would lead to undercounts.

\section{B1/ Headline comparisons}

The 2011 BSD contains 2.161m enterprises, but excludes sole traders and many SMEs. Our 'true sample' of quasi-enterprises contains 2.460m observations as of August 2012 when 
firms without SICs are included, so the BSD figure is within $88 \%$ of this: acceptable given the differences in time and sample coverage.

Table B1 shows the headline estimates for the two datasets. The 2011 BSD contains $2.161 \mathrm{~m}$ enterprises, of which $5.78 \%$ (124,971 enterprises) are 'information economy' businesses.

\section{[Table B1 about here]}

In Companies House, around 1.9m 'quasi-enterprises' are present in 2011. Quasi-enterprises are companies that have gone through our cleaning steps (see Section 4 of the main report). $8.2 \%$ of our sample $(153,858$ quasi-enterprises $)$ is in the information economy.

Table B2 gives more detail on the internal structure of the set of information economy firms, reporting counts and shares at SIC5 level. We can see that SIC bins have different shares in the two datasets. Typically these differences in shares are small, although there are some exceptions. One group consists of sectors where both counts and shares are low, such as 'manufacturing of telephone and telegraph equipment' (1.07\% of the BSD set, $0.45 \%$ of the $\mathrm{CH}$ set, SIC 26301). The other group consists of larger cells, such as 'business and domestic software development' (14.28\% of the BSD set, $12.05 \%$ of the CH set, SIC 62012); 'information technology consultancy' $(52.88 \%, 42.45 \%, 62020)$ and 'other information technology service activities' $(17.96 \%, 27.7 \%, 62090)$.

\section{[Table B2 about here]}

What might explain these differences? The rest of the Appendix tests possible channels.

\section{B2/ Age structures}

There are structural differences between the BSD and Companies House (Anyadike-Danes, 2011). The BSD covers $99 \%$ of businesses in the UK. But by definition, the BSD excludes firms that do not pay VAT and/or do not have employees on PAYE. For this reason it will tend to select older and more established firms than $\mathrm{CH}$. Similarly, in sectors with low entry barriers - such as many information economy sectors $-\mathrm{CH}$ will tend to report larger numbers 
of observations than the BSD, but coverage in the BSD may be 'skewed' towards more established organisations. ${ }^{22}$ Looking at the age structure of firms in the BSD and $\mathrm{CH}$, we can see that the BSD coverage is orientated towards older firms than $\mathrm{CH}$ (Table B3):

\section{[Table B3 about here]}

Around $52 \%$ of BSD firms appear in the last 10 years (and about $17 \%$ of start-ups, defined as firms three years old or less). In contrast, $67 \%$ of $\mathrm{CH}$ observations are founded in the last 10 years and $21 \%$ of $\mathrm{CH}$ observations start-ups. These differences are also noticeable in the information economy (Table B4). The differences are smaller for the set of firms 10 years old or less, but greater for start-ups:

\section{[Table B4 about here]}

We know that information economy sectors are typically characterised by low entry barriers, high levels of innovation and a lot of young firms (Department for Business Innovation and Skills, 2013). So counts / shares of such firms are likely to be higher in $\mathrm{CH}$, even if estimates of sector-level employment / turnover will not differ much.

\section{B3/ Sectoral distribution in the BSD and $\mathrm{CH}$}

Next we look at levels and shares for all 735 SIC5 bins, for both datasets. Manual examination reveals some trivial differences. First, around $29 \mathrm{CH}$ observations have invalid SIC codes ( $0.0016 \%$ of the $\mathrm{CH}$ sample). Second, some sectors are present in $\mathrm{CH}$ but absent in the BSD, for example households as employers (including 59,194 residential property management companies, $3.17 \%$ of the $\mathrm{CH}$ sample); space transport (22 observations); growing citrus fruits (2), oleaginous fruits (1), gathering wild growing products (19). Third, holding companies are present in the BSD but not $\mathrm{CH}$ because our cleaning kicks them out. In the BSD they comprise 14,281 observations, or $0.66 \%$ of the sample.

Figure B1 scatters the full set of bins for both datasets and illustrates each bin's share. The overall distribution of $\mathrm{CH}$ and the BSD is fairly close - see the two best fit lines - although

\footnotetext{
22 In practice, these comparisons understate the true differences, since the BSD/IDBR 'birth' variable measures time of entry into the dataset rather than true birth year of the business.
} 
this hides some differences (in particular 'Other business support activities not elsewhere classified' (9.93\% of CH, 2.92\% of the BSD, SIC 82990) and 'Other business services not elsewhere classified' (3.17\% of CH, 1.7\% of the BSD, SIC 96090). We discuss other cases below in 6.1 .

\section{[Figure B1 about here]}

For the information economy, we can see that the matching is generally pretty good although there are three exceptions. As highlighted above these are 'business and domestic software development' (14.28\% of the BSD set, 12.05\% of the CH set, SIC 62012); 'information technology consultancy' $(52.88 \%, 42.45 \%, 62020)$ and 'other information technology service activities' $(17.96 \%, 27.7 \%, 62090)$. Figure B2 illustrates.

\section{[Figure B2 about here]}

We can see that in most cases, $\mathrm{CH}$ and BSD \% differences are minimal / zero (Figure B3):

\section{[Figure B3 about here]}

\section{B4/ Exploring the extremes}

We now look at the approximately $10 \%$ of SIC bins where the differences are most pronounced (tables B5 and B6, below). Specifically, we take the 37 bins at each end of the distribution above - the tails - where BSD-CH differences are greatest (in one direction or the other). ${ }^{23}$

\section{B4.1 / CH > BSD shares}

First we look at the bins where sector shares are higher in $\mathrm{CH}$ than the BSD. Results are given in Table B5. A large number of the bins are 'other' or 'not elsewhere classified' (NEC) type sectors. While we do not directly observe the assignment process, this is consistent with $\mathrm{CH}$ processes generating some of these differences. Four of these bins are 'information

\footnotetext{
${ }^{23}$ Specifically, we are looking at $(74 / 735) * 100=10.07 \%$ of the whole.
} 
economy' sectors (see highlights key). In particular, there are far more CH firms in 62090, 'other information technology service activities', than in the BSD. In the BSD, firms in the 62090 bin are slightly older than the BSD, DE and IE averages, and a lot older in terms of age structure. The relevant firms in Companies House are much younger than their BSD counterparts.

\section{[Table B5 about here]}

However, real estate and construction sector bins also exhibit large BSD-CH differences. We can speculate about the reasons for this. For instance, it is possible that $\mathrm{CH}$ shares are generally higher for sectors that have low entry barriers and lots of small players. In addition, retail and construction may both involve extensive use of temporary contracts and/or freelancing rather than PAYE employment.

\section{B4.2/ BSD > CH shares}

Results are set out in Table B6. This is a harder group to summarise. Only six bins are 'NEC' sectors. Notably, none of the bins is in our information economy sector set. Seven of the bins are agricultural sectors that likely exhibit large economies of scale and entry barriers. As before, we can speculate about the likely common characteristics of firms in these cells: many might tend to be labour-intensive (pubs and bars, speciality retail, solicitors, barristers), exhibit large economies of scale (construction of domestic buildings, freight shifting) or both.

\section{[Table B6 about here]}

Again, this suggests that industry-specific characteristics (age structure, entry barriers, economies of scale, input choices) might explain at least some BSD $>\mathrm{CH}$ differences. It is also consistent with $\mathrm{CH}$ self-assignment producing some of the differences. 


\section{B5/ Discussion}

Overall, comparison of the BSD and Companies House shows that the majority of sectors are well matched. However, the bins where there are differences account for a non-trivial share of observations.

The analysis above confirms that the different sampling frames of the BSD and $\mathrm{CH}$ produce some differences in levels and internal structure, even after cleaning Companies House data to make quasi-enterprises. In part these reflect real differences in company and sector characteristics, such as firm age, industry structures and entry barriers. This is not a cause for concern, but implies that we need to take care in making direct comparisons.

We have also tested whether Companies House processes create any sampling bias for information economy analysis. The overall distribution of $\mathrm{CH}$ and BSD SIC5 bins is well matched. However, in the bins where differences are most pronounced, we find a number of 'not elsewhere classified' bins where Companies House counts are higher than their BSD counterparts, four of which are in the information economy. That is consistent with selfassignment 'pushing' some firms into particular bins rather than their 'true' location. In turn, this suggests that information economy counts might be higher than true in $\mathrm{CH}$ data.

How large a problem is this? Overall, around $10 \%$ of observations in the raw $\mathrm{CH}$ data are in NEC bins. Conversely, over $20 \%$ of observations lack any SIC coding. Again, this is consistent with $\mathrm{CH}$ rules leading to non-assignment, and as we have discussed, plausibly biases information economy counts down in our benchmarking sample. Comparing these two magnitudes suggests that information economy counts and shares in our benchmarking sample are more likely to be lower bounds, not upper bounds. 


\section{APPENDIX B: LIST OF TABLES AND FIGURES}

Table B1. Information economy counts and shares: BSD vs Companies House 2011.

\begin{tabular}{|l|c|c|}
\hline Enterprise / QE type & Freq. & Percent \\
\hline$B S D$ & & \\
Other & $2,036,557$ & 94.22 \\
Information economy mf + services & 124,971 & 5.78 \\
Total & $2,161,538$ & \\
\hline Companies House & & \\
Other & $1,722,359$ & 91.81 \\
Information economy mf + services & 153,858 & 8.20 \\
Total & $1,876,217$ & \\
\hline
\end{tabular}

Source: BSD, Companies House

Notes: $\mathrm{BSD}=$ enterprises, $\mathrm{CH}=$ quasi-enterprises. 
Table B2. Information economy: shares and counts for component bins, 2011.

\begin{tabular}{|c|c|c|c|c|c|c|}
\hline \multirow{2}{*}{ SIC5 sector name } & \multicolumn{3}{|c|}{ BSD } & \multicolumn{3}{|c|}{$\mathbf{C H}$} \\
\hline & Freq. & Percent & Cum. & Freq. & Percent & Cum. \\
\hline $\mathrm{mf}$ of loaded electronic boards & 360 & 0.29 & 0.76 & 241 & 0.16 & 0.83 \\
\hline $\mathrm{mf}$ of telephone and telegraph equipment & 1,342 & 1.07 & 2.49 & 700 & 0.45 & 1.8 \\
\hline $\mathrm{mf}$ of other communications equipment & 163 & 0.13 & 2.62 & 199 & 0.13 & 1.93 \\
\hline $\mathrm{mf}$ of consumer electronics & 614 & 0.49 & 3.12 & 487 & 0.32 & 2.25 \\
\hline $\mathrm{mf}$ of electronic industrial process control equipment & 259 & 0.21 & 4.59 & 512 & 0.33 & 3.26 \\
\hline $\mathrm{mf}$ of non-electronic equipment not for ipc & 185 & 0.15 & 4.73 & 42 & 0.03 & 3.29 \\
\hline mf of non-electronic ipc equipment & 92 & 0.07 & 4.81 & 20 & 0.01 & 3.3 \\
\hline mf of optical precision instruments & 123 & 0.1 & 4.91 & 128 & 0.08 & 3.38 \\
\hline $\mathrm{mf}$ of photographic and cinematographic equipment & 88 & 0.07 & 4.98 & 64 & 0.04 & 3.43 \\
\hline mf of magnetic and optical media & 26 & 0.02 & 5 & 33 & 0.02 & 3.45 \\
\hline wireless telecomms activities & 657 & 0.53 & 7.69 & 1,413 & 0.92 & 7.71 \\
\hline satellite telecomms activities & 130 & 0.1 & 7.8 & 372 & 0.24 & 7.95 \\
\hline other telecomms activities & 5,208 & 4.17 & 11.97 & 7,658 & 4.98 & 12.93 \\
\hline ready-made interactive leisure, entertainment software & 623 & 0.5 & 12.46 & 2,459 & 1.6 & 14.53 \\
\hline business and domestic software development & 17,842 & 14.28 & 26.74 & 18,540 & 12.05 & 26.58 \\
\hline information technology consultancy activity & 66,090 & 52.88 & 79.62 & 65,319 & 42.45 & 69.03 \\
\hline computer facilities management activities & 207 & 0.17 & 79.79 & 2,212 & 1.44 & 70.47 \\
\hline other information technology service activities & 22,444 & 17.96 & 97.75 & 42,614 & 27.7 & 98.17 \\
\hline data processing hosting and related activities & 2,812 & 2.25 & 100 & 2,819 & 1.83 & 100 \\
\hline Total & 124,971 & 100 & & 153,858 & 100 & \\
\hline
\end{tabular}

Source: BSD, Companies House // Notes: BSD = enterprises, CH = quasi-enterprises 
Table B3. Age structure for all sectors, BSD vs Companies House 2011.

\begin{tabular}{|c|c|c|c|c|}
\hline Birth year & Freq. & Percent & Cum. & inverse \\
\hline$B S D$ & & & & \\
\hline 2002 & 97,427 & 4.51 & 48.17 & 51.83 \\
2003 & 104,285 & 4.82 & 52.99 & 47.01 \\
2004 & 93,431 & 4.32 & 57.31 & 42.69 \\
2005 & 105,061 & 4.86 & 62.17 & 37.83 \\
2006 & 132,971 & 6.15 & 68.33 & 31.67 \\
2007 & 163,062 & 7.54 & 75.87 & 24.13 \\
2008 & 150,699 & 6.97 & 82.84 & 17.16 \\
2009 & 171,379 & 7.93 & 90.77 & 9.23 \\
2010 & 164,360 & 7.6 & 98.37 & 1.63 \\
2011 & 35,152 & 1.63 & 100 & 0 \\
Total & $2,161,538$ & 100 & & \\
\hline Companies House & & & & \\
\hline 2002 & 85,071 & 4.53 & 32.93 & 67.07 \\
2003 & 114,892 & 6.12 & 39.05 & 60.95 \\
2004 & 89,635 & 4.78 & 43.83 & 56.17 \\
2005 & 98,829 & 5.27 & 49.1 & 50.9 \\
2006 & 115,940 & 6.18 & 55.28 & 44.72 \\
2007 & 144,991 & 7.73 & 63.01 & 36.99 \\
2008 & 135,701 & 7.23 & 70.24 & 29.76 \\
2009 & 165,044 & 8.8 & 79.03 & 20.97 \\
2010 & 216,961 & 11.56 & 90.6 & 9.4 \\
2011 & 176,397 & 9.4 & 100 & 0 \\
Total & $1,876,217$ & 100 & & \\
\hline
\end{tabular}

Source: BSD, Companies House

Notes: BSD = enterprises, $\mathrm{CH}=$ quasi-enterprises. BSD enterprises measured by oldest local unit year of entry into the IDBR. CH QE age measured by year incorporated. 
Table B4. Age structure for information economy sectors, BSD vs Companies House 2011.

\begin{tabular}{|c|c|c|c|c|}
\hline Birth year & Freq. & Percent & Cum. & inverse \\
\hline$B S D$ & & & & \\
\hline 2002 & 6,962 & 3.92 & 42.1 & 57.9 \\
2003 & 8,199 & 4.61 & 46.71 & 53.29 \\
2004 & 8,989 & 5.06 & 51.76 & 48.24 \\
2005 & 9,903 & 5.57 & 57.33 & 42.67 \\
2006 & 11,270 & 6.34 & 63.67 & 36.33 \\
2007 & 17,135 & 9.64 & 73.31 & 26.69 \\
2008 & 13,363 & 7.51 & 80.82 & 19.18 \\
2009 & 13,574 & 7.63 & 88.45 & 11.55 \\
2010 & 16,840 & 9.47 & 97.92 & 2.08 \\
2011 & 3,691 & 2.08 & 100 & 0 \\
Total & 177,821 & 100 & & \\
\hline Companies House & & & & \\
2002 & 5,364 & 3.49 & 29.34 & 70.66 \\
2003 & 6,577 & 4.27 & 33.61 & 66.39 \\
2004 & 6,748 & 4.39 & 38 & 62 \\
2005 & 7,288 & 4.74 & 42.73 & 57.27 \\
2006 & 9,120 & 5.93 & 48.66 & 51.34 \\
2007 & 14,304 & 9.3 & 57.96 & 42.04 \\
2008 & 12,309 & 8 & 65.96 & 34.04 \\
2009 & 14,665 & 9.53 & 75.49 & 24.51 \\
2010 & 20,969 & 13.63 & 89.12 & 10.88 \\
2011 & 16,740 & 10.88 & 100 & 0 \\
Total & 153,858 & 100 & & \\
\hline & & & & \\
\hline
\end{tabular}

Source: BSD, Companies House

Notes: $\mathrm{BSD}=$ enterprises, $\mathrm{CH}=$ quasi-enterprises. $\mathrm{BSD}$ enterprises measured by oldest local unit year of entry into the IDBR. CH QE age measured by year incorporated. 
Table B5. 5\% of SIC5 bins with largest CH-BSD differences, 2011.

\begin{tabular}{|c|c|c|c|}
\hline SIC2007 5-digit category & $\%$ BSD & $\% \mathrm{CH}$ & BSD - CH \\
\hline other business support activities nec & 2.92 & 9.93 & -7.01 \\
\hline residents property management & 0 & 3.17 & -3.17 \\
\hline other business services nec & 1.7 & 3.19 & -1.49 \\
\hline buying and selling of own real estate & 0.14 & 1.49 & -1.35 \\
\hline other information technology service activities & 1.04 & 2.28 & -1.24 \\
\hline activities of head offices & 0.12 & 1.31 & -1.19 \\
\hline management of real estate on fee/contract basis & 0.53 & 1.47 & -0.94 \\
\hline other professional, scientific and technical activities nec & 1.18 & 2.09 & -0.91 \\
\hline financial intermediation nec & 0.19 & 0.95 & -0.76 \\
\hline other letting and renting of own / leased real estate & 1.94 & 2.64 & -0.7 \\
\hline development of building projects & 1.65 & 2.31 & -0.66 \\
\hline other human health activities & 0.55 & 1.2 & -0.65 \\
\hline other building completion and finishing & 0.64 & 1.19 & -0.55 \\
\hline other manufacturing nec & 0.24 & 0.73 & -0.49 \\
\hline information technology consultancy activities & 3.06 & 3.49 & -0.43 \\
\hline construction of commercial buildings & 0.71 & 1.11 & -0.4 \\
\hline Other amusement and recreation activities nec & 0.21 & 0.57 & -0.36 \\
\hline other information service activities & 0.09 & 0.41 & -0.32 \\
\hline renting and operating of housing association real estate & 0.27 & 0.58 & -0.31 \\
\hline other accommodation & 0.02 & 0.31 & -0.29 \\
\hline other sports activities & 0.13 & 0.41 & -0.28 \\
\hline other food activities & 0.06 & 0.26 & -0.2 \\
\hline other retail sale not in stores, sales or market & 0.49 & 0.69 & -0.2 \\
\hline educational support activities & 0.04 & 0.22 & -0.18 \\
\hline sound recording and music publishing activities & 0.1 & 0.27 & -0.17 \\
\hline other telecomms activities & 0.24 & 0.41 & -0.17 \\
\hline business and domestic software development & 0.83 & 0.99 & -0.16 \\
\hline motion picture production & 0.23 & 0.39 & -0.16 \\
\hline technical and vocational secondary education & 0.1 & 0.26 & -0.16 \\
\hline other construction installation & 0.28 & 0.44 & -0.16 \\
\hline other publishing activities & 0.13 & 0.29 & -0.16 \\
\hline specialists medical practice activities & 0.08 & 0.24 & -0.16 \\
\hline repair of other equipment & 0.04 & 0.19 & -0.15 \\
\hline manufacture of other fabricated metal products nec & 0.19 & 0.33 & -0.14 \\
\hline video production activities & 0.05 & 0.18 & -0.13 \\
\hline non-life insurance & 0.07 & 0.2 & -0.13 \\
\hline hospital activities & 0.04 & 0.17 & -0.13 \\
\hline
\end{tabular}

Source: BSD, Companies House

Notes: $\mathrm{BSD}=$ enterprises, $\mathrm{CH}=$ quasi-enterprises. Shaded $=$ information economy SIC5 bin. 
Table B6. 5\% of SIC5 bins with largest BSD-CH differences, 2011.

\begin{tabular}{|c|c|c|c|}
\hline SIC2007 5-digit category & \% BSD & $\% \mathrm{CH}$ & BSD - CH \\
\hline general cleaning of buildings & 0.45 & 0.22 & 0.23 \\
\hline security and commodity deal contracts & 0.28 & 0.05 & 0.23 \\
\hline raising of other cattle and buffaloes & 0.26 & 0.02 & 0.24 \\
\hline temporary employment agency activities & 0.62 & 0.37 & 0.25 \\
\hline Painting & 0.54 & 0.28 & 0.26 \\
\hline wholesale of other machinery and equipment & 0.36 & 0.1 & 0.26 \\
\hline activities of religious organisations & 0.41 & 0.14 & 0.27 \\
\hline general medical practice activities & 0.71 & 0.43 & 0.28 \\
\hline management consultancy other than financial & 5.06 & 4.76 & 0.3 \\
\hline activities auxiliary to financial intermediation nec & 0.49 & 0.19 & 0.3 \\
\hline other social work activities nec & 0.75 & 0.45 & 0.3 \\
\hline construction of other civil engineering projects & 0.8 & 0.5 & 0.3 \\
\hline unlicensed restaurants and cafes & 0.58 & 0.26 & 0.32 \\
\hline Solicitors & 0.6 & 0.28 & 0.32 \\
\hline specialised design activities & 0.76 & 0.44 & 0.32 \\
\hline activities of other holding companies & 0.33 & 0 & 0.33 \\
\hline unlicensed carriers & 0.45 & 0.08 & 0.37 \\
\hline licensed clubs & 0.42 & 0.05 & 0.37 \\
\hline other sale of new goods in specialised stores & 0.89 & 0.5 & 0.39 \\
\hline growing of vegetables, roots and tubers & 0.45 & 0.05 & 0.4 \\
\hline machining & 0.58 & 0.17 & 0.41 \\
\hline barristers at law & 0.45 & 0.01 & 0.44 \\
\hline child day-care & 0.51 & 0.07 & 0.44 \\
\hline electrical installation & 1.75 & 1.27 & 0.48 \\
\hline freight transport by road & 1.34 & 0.86 & 0.48 \\
\hline construction of domestic buildings & 1.31 & 0.82 & 0.49 \\
\hline landscape service activities & 0.78 & 0.28 & 0.5 \\
\hline joinery installation & 1.02 & 0.45 & 0.57 \\
\hline growing of cereals & 0.78 & 0.2 & 0.58 \\
\hline plumbing, heating and air-con & 1.39 & 0.8 & 0.59 \\
\hline raising of dairy cattle & 0.72 & 0.07 & 0.65 \\
\hline raising of horses & 0.71 & 0.03 & 0.68 \\
\hline hairdressing and other beauty equipment & 1.41 & 0.66 & 0.75 \\
\hline maintenance and repair of motor vehicles & 1.67 & 0.88 & 0.79 \\
\hline take-away shops and mobile food stands & 1.31 & 0.39 & 0.92 \\
\hline retail sale with food, beer predominating & 1.33 & 0.36 & 0.97 \\
\hline pubs and bars & 1.6 & 0.53 & 1.07 \\
\hline
\end{tabular}

Source: BSD, Companies House

Notes: $\mathrm{BSD}=$ enterprises, $\mathrm{CH}=$ quasi-enterprises. 
Figure B1. Comparing BSD and CH shares, all SIC5 sectors, 2011.

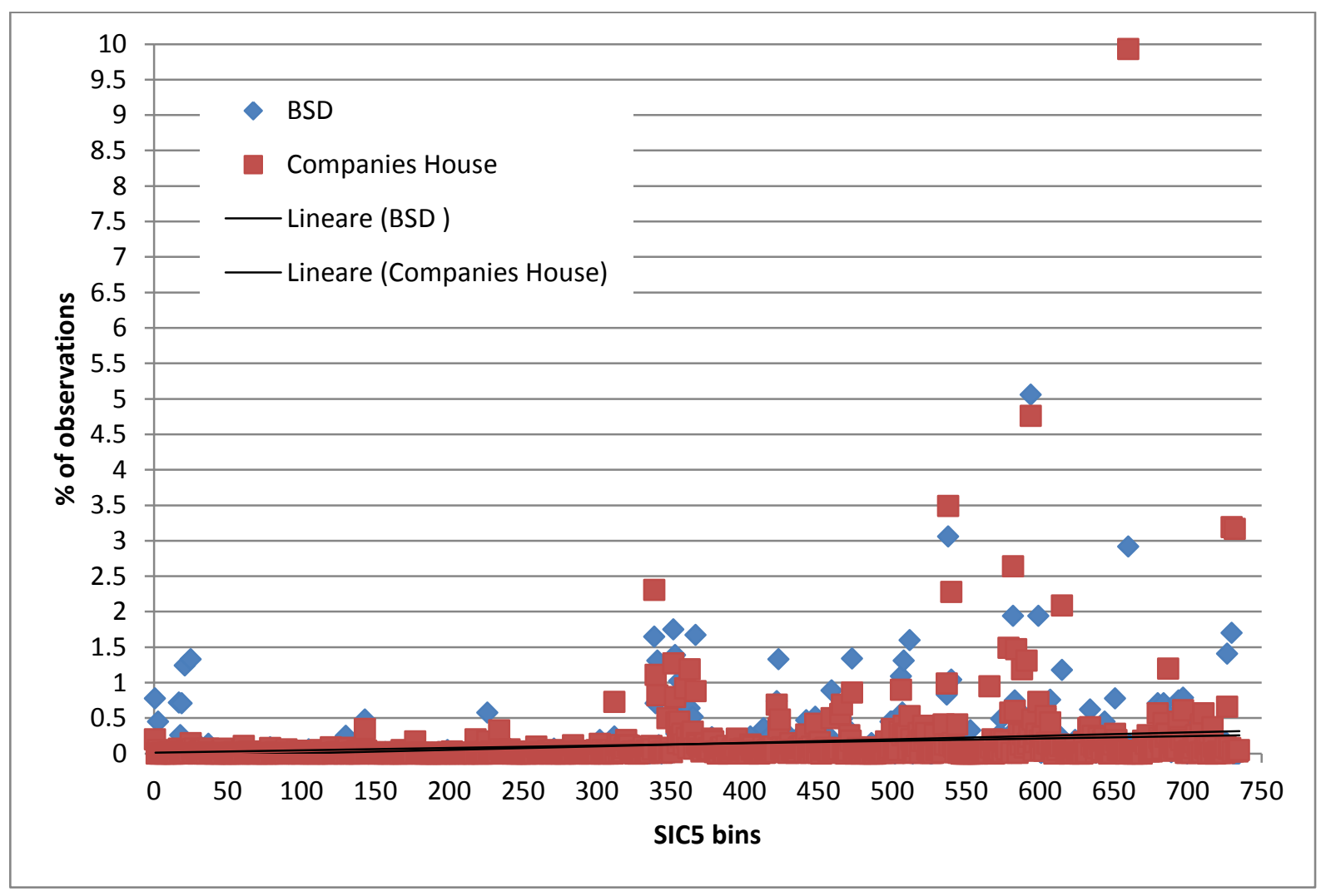

Source: BSD, Companies House

Notes: $\mathrm{BSD}=$ enterprises, $\mathrm{CH}=$ quasi-enterprises. 
Figure B2. Comparing BSD and CH shares, info economy sectors, 2011.

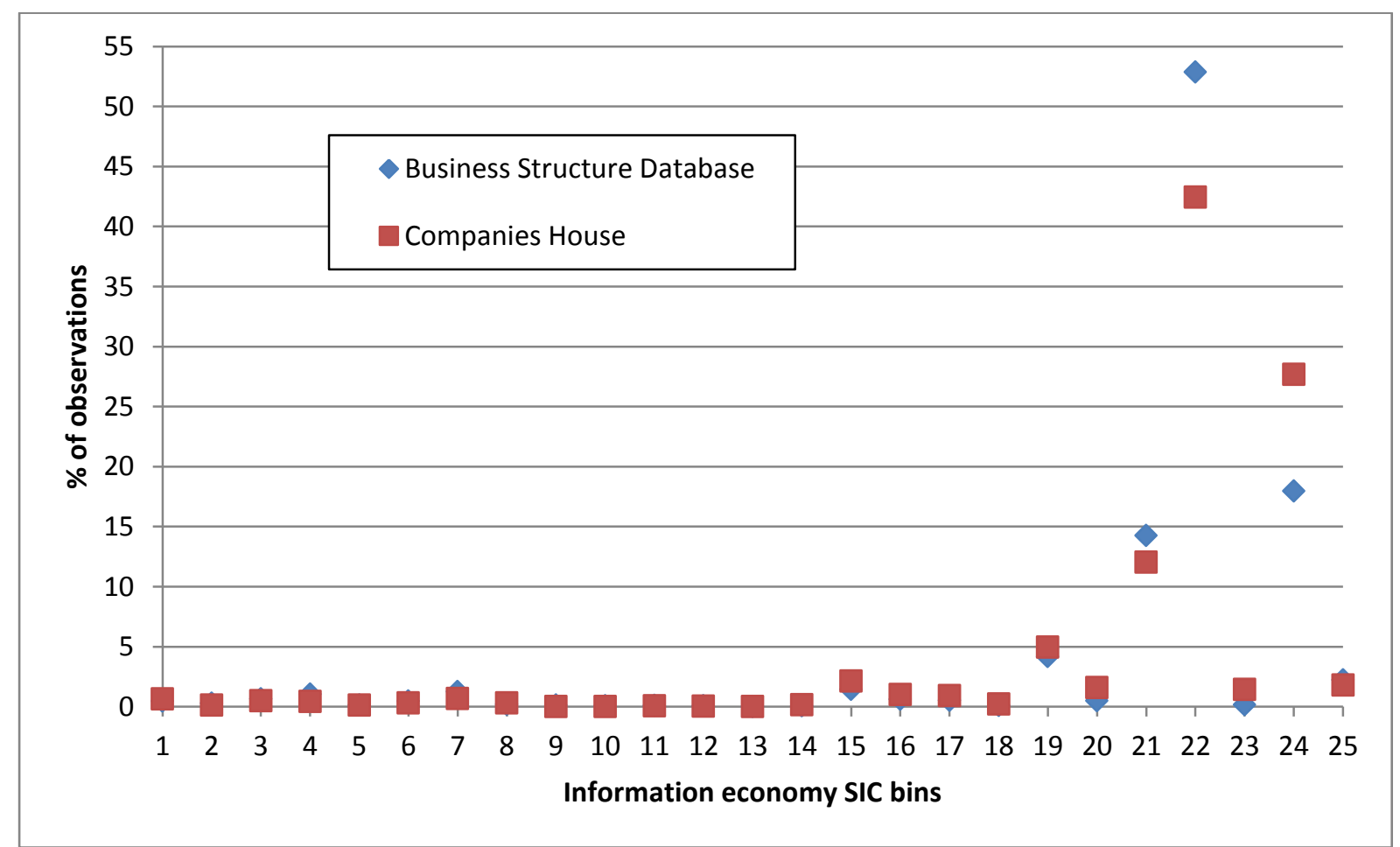

Source: BSD, Companies House

Notes: $\mathrm{BSD}=$ enterprises, $\mathrm{CH}=$ quasi-enterprises.

Figure B3. Comparing BSD and CH differences, 2011.

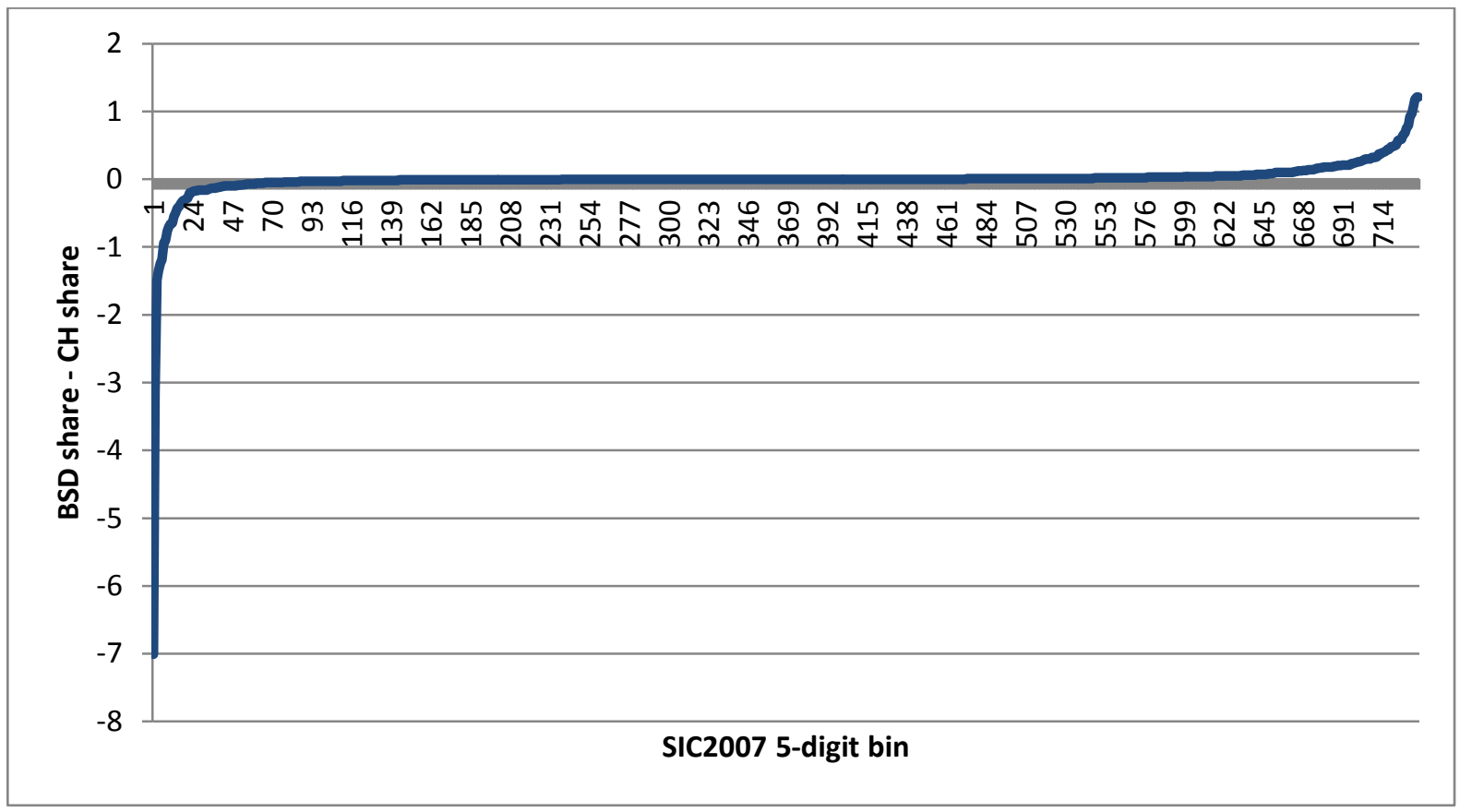

Source: BSD, Companies House

Notes: $\mathrm{BSD}=$ enterprises, $\mathrm{CH}=$ quasi-enterprises. 